\title{
القيم الأخلاقية والعلوم الاجتماعية: نحو إبستمولوجية القيم الحاكمة
}

\section{عبد الززاق بلعقروز}

$$
\begin{aligned}
& \text { الملخص } \\
& \text { يناقش هذا البحث النموذج المعري السائد حول صلة القيم الأخلاقية بالعلوم الاجتماعية، خاصّةً في الميدان } \\
& \text { النفسي؛ إذ تطالعنا المساءلة التحليلية بهيمنة نموذج الفصل بين القيمة والمعرفة لأسباب ترتبط بالنموذج الحداثي، الذي } \\
& \text { قـام على مبـدأ عزل الأخهاق عن العلوم، والرؤيـة التجزيئيـة للقيم ضـمن نظريـات القيمـة المعاصـرة؛ مـا أورث علوماً } \\
& \text { اجتماعيةً مأزومةً إبستمولوجياً، وغير محيطة بمختلف جوانب الإنسان، ممّا اقتضى بتحيد منهج النظر في الصلة المُمزَّقة } \\
& \text { بين القيم والعلوم الاجتماعية؛ استئناساً بالخبرة الحضارية، واعتماداً على نموذج حاكمية القيمة على المعرفة الإنسانية، }
\end{aligned}
$$

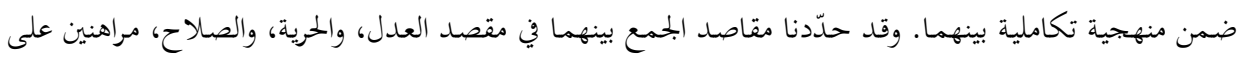

$$
\begin{aligned}
& \text { منظومة التربية والتعليم بوصفها أوعيةً لنقل هذا الأمل من الوجود المثالي إلى الوجود الواقعي. }
\end{aligned}
$$

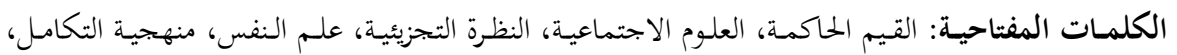

$$
\begin{aligned}
& \text { العدل، الصلاح، الحرية. }
\end{aligned}
$$

\section{Ethical Values and Social Sciences: \\ Towards a Dominant-Values Epistemology}

Abstract

This article discusses the dominant paradigm on the relationship between values and Social sciences, especially psychology. The analysis of such relationship would find a paradigm of separation between value and knowledge, due to the model of modernity that stands on isolating morals from sciences, and to the fragmentary viewpoint of contemporary theories of values. As a result of this we have an epistemological crisis in social sciences that do not cover various aspects of human realities. This has necessitated the need to reconsider this torn relationships making use of the civilizational experience, and depending on the paradigm of supremacy of values on human knowledge, within an integrated methodology. To do just that we have identified three combing purposes, i.e.: justice, freedom, and soundness. System of education should be the means to transfer this hope from its ideal form into reality.

Key words: Governing values, social sciences, fragmentary viewpoint, psychology, integrated methodology, justice, soundness, freedom

* دكتوراه في الفلسفة، أستاذ فلسفة القيم، عضو مؤسس الجمعية الجزائرية للدراسات الفلسفية، جامعة محمد لمـين دباغين سطيف r/ الجزائر. البريد الإلكتروني: yahoo.fr

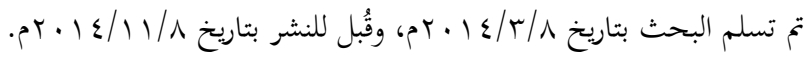




\section{مقدمة: - مق}

مدار الفكرة الرئيسة لمذه الإشكالية البحثية هو إعـادة بنـاء منهج النظر إلى القيم

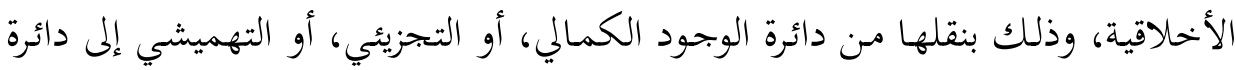

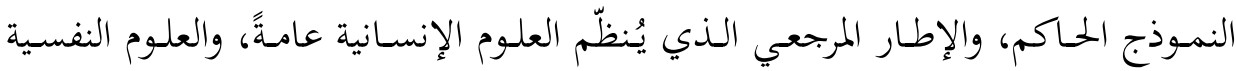
بوجه خاص؛ إذ لا يتم تناول القيم الأخلاقية بوصفها معوّقات إبستمولوجية فيما أسميناه

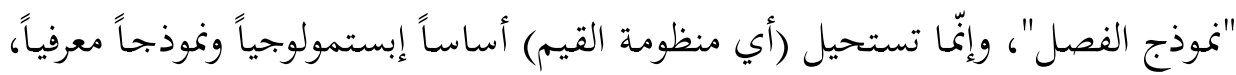
أو مفهومَ الأصل والواصل، ومفهومَ المظلّة، ومفهومَ العائلة أيضاً.

وتبنّي هـا الرأي يقتضي أيضاً تجديد مفهوم القيم الأخلاقية؛ تماشياً مع شموليتها

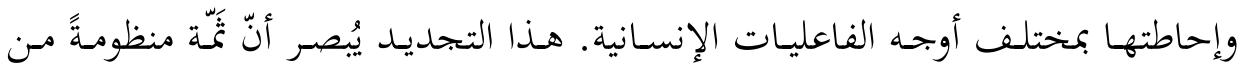

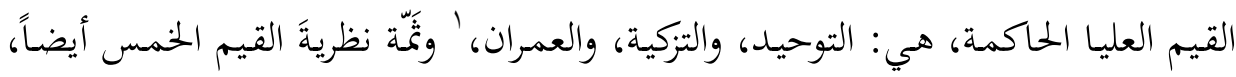

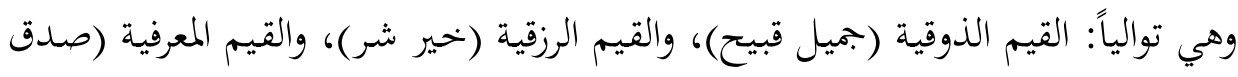

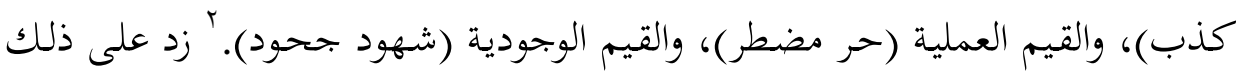

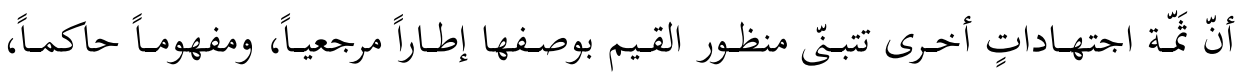
وتُفصِّلها على النحو الآتي:

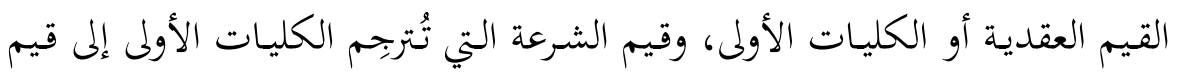

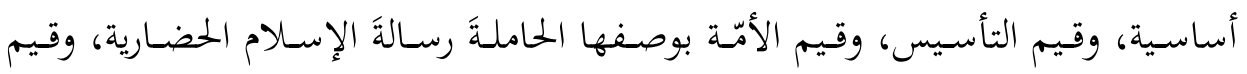

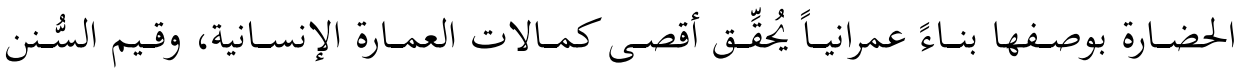

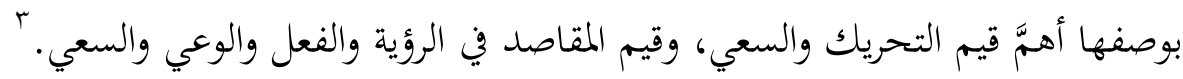

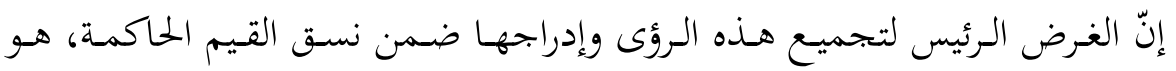

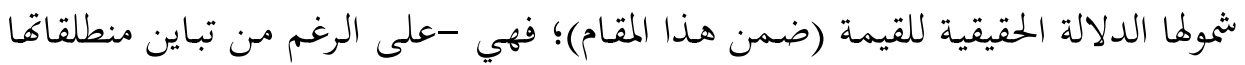




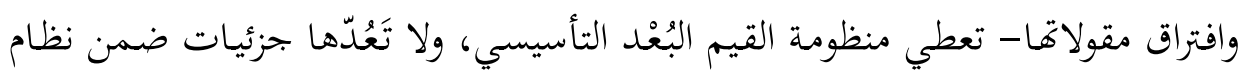

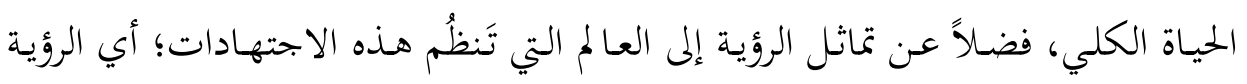
التوحيدية الكلية للوجود.

يُذكَر أنّ تبنيّ هذه الاجتهادات يزيد من درجة فصل القيمة عن المعرفة عامة، وعن

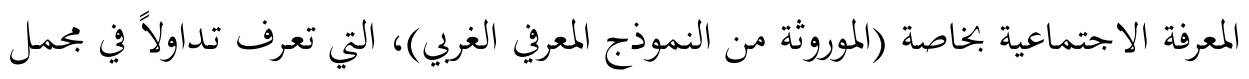

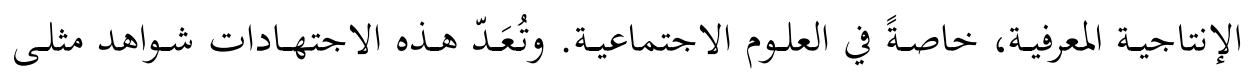
على بتحديد سؤال القيم وتفعيله في الفكر الإسلامي المعاصر. إنّنا في تساؤلاتنا ضمن هذا الإطار سنعمل على استثمار هذه النظريات، ونستأنس

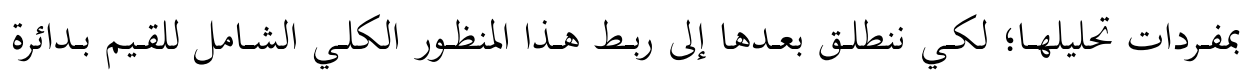

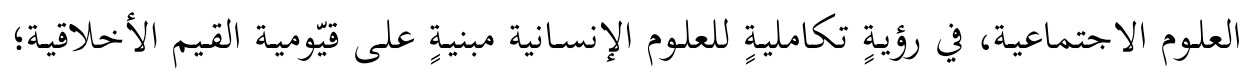

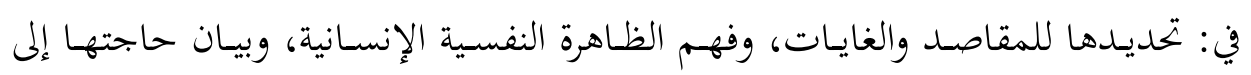

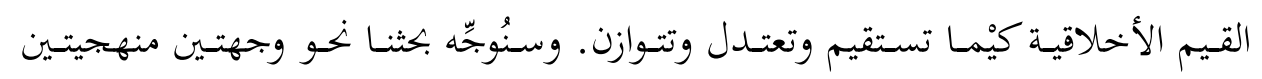
أساسيتين، هما:

- الوجهة التراثية الحضارية الإسلامية وإبحازاتا في إيجاد التوجيه الأخلاقي للمباحث النفسية، واستثمار معطيات المنهجية التراثية الفاعلة في هذا المحال.

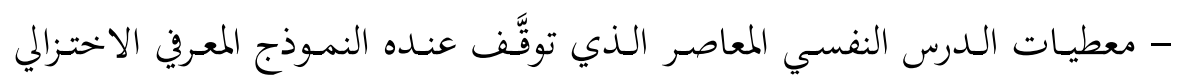

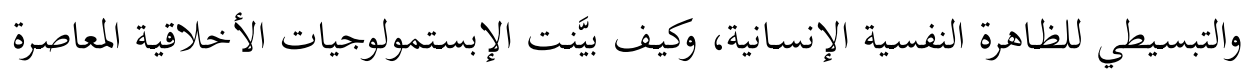
مدى الحاجة إلى القيم الأخلاقية لكي تكون "نماذج حاكمة، أو عناصر تأسيسية"، يُجقِق الإنق هـا الإنسان المعاصر العبور من الوجود الطبيعي إلى الوجود الأخلاقي. تكمن أهمية هذا الموضوع الذي يتناول مشكلات الفكر المكر الإنساني المعاصرة في الآيت:

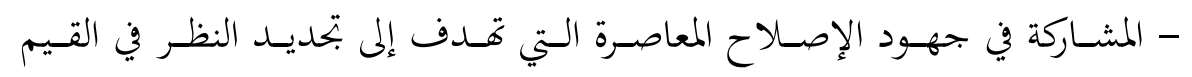

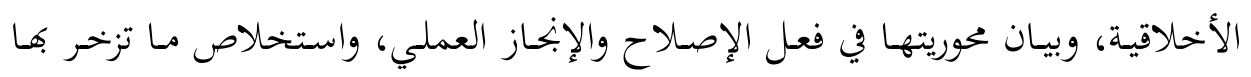
الحضارة الإسلامية من نظم أخلاقية بحدها مبثوثة في مصادر التشريع الإسلامية. 


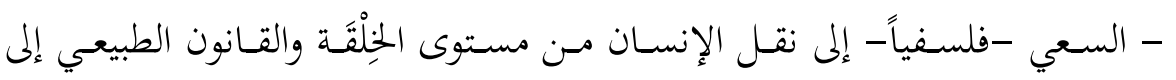
مستوى القيمة والقانون الأخلاقي.

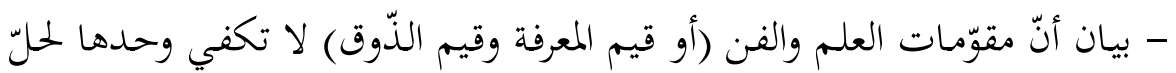

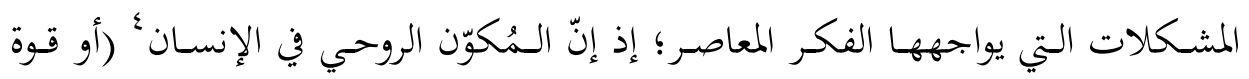

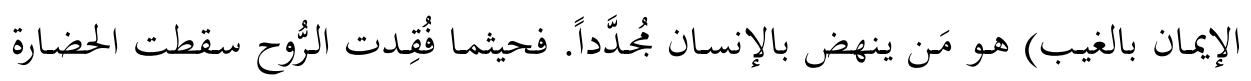

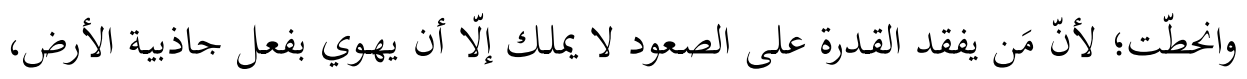

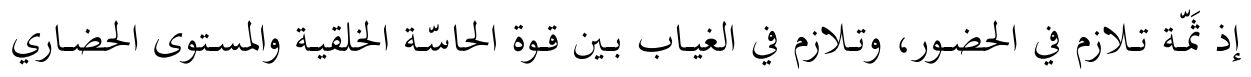

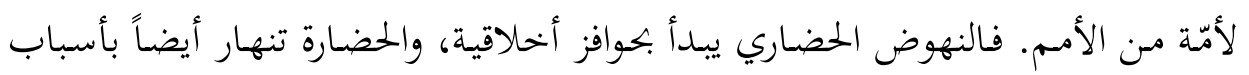

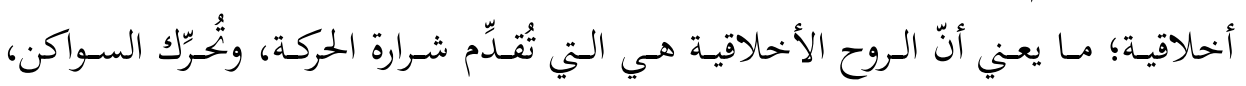

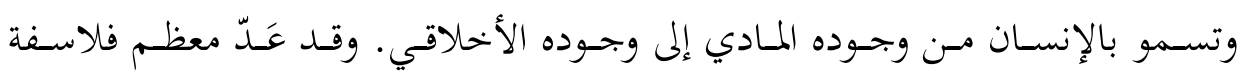

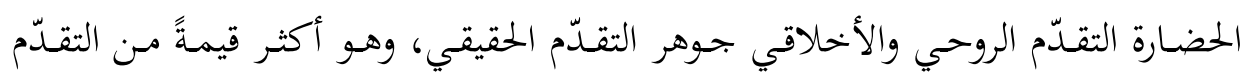

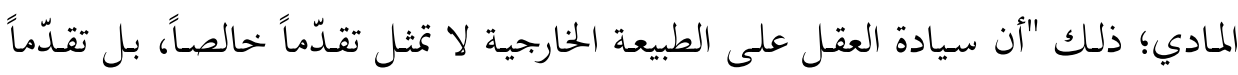

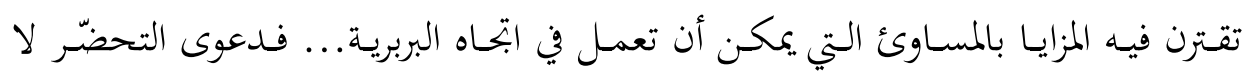

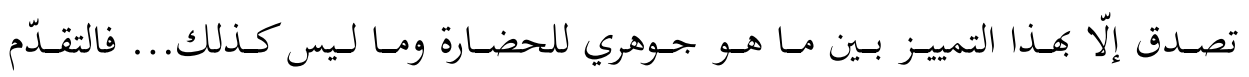

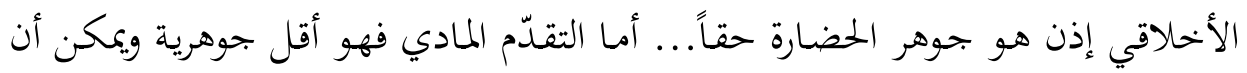

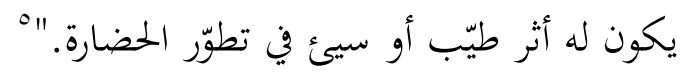

\section{أولاً: مسوّغات تجديد منهاج النظر في القيم الخلقية وصلتها بالعلوم النفسية}

قبل الحمديث في هذا الموضوع، مـ الأقوم لنا منهجياً الإشارة إلى دلالة الكلمات

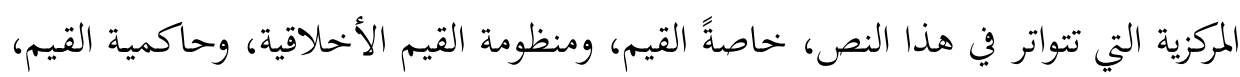

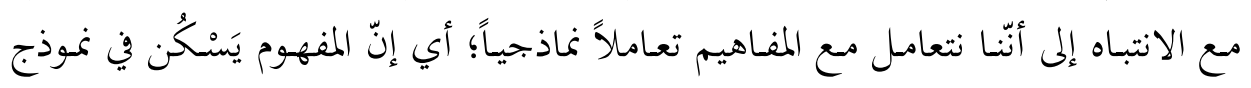

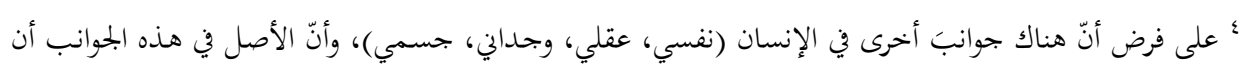

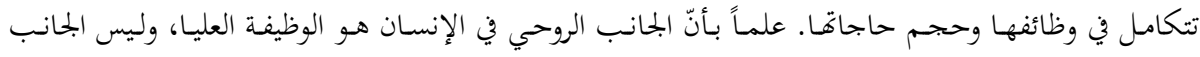

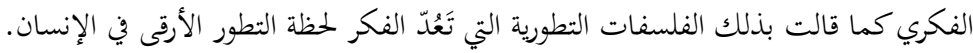

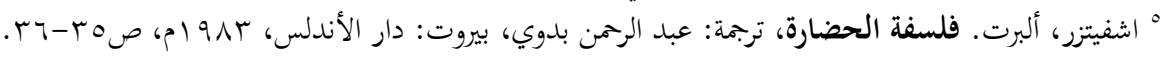




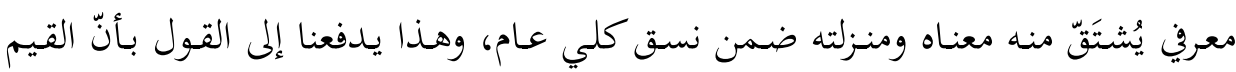
والمنظومة الأخلاقية ينطبق عليها مثل هذا الإجراء المنهجي.

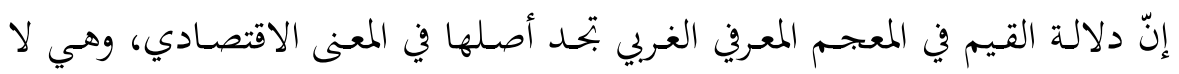

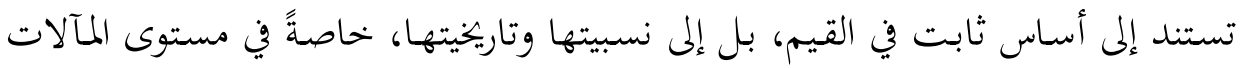

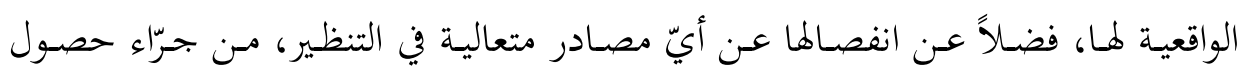

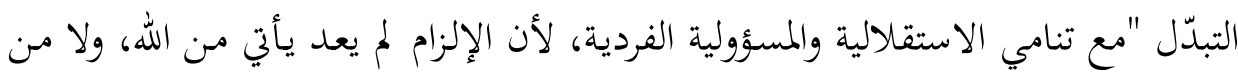

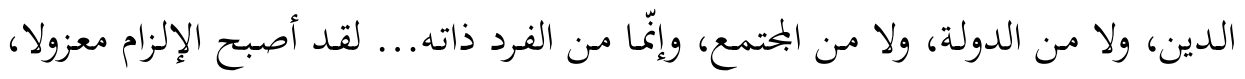

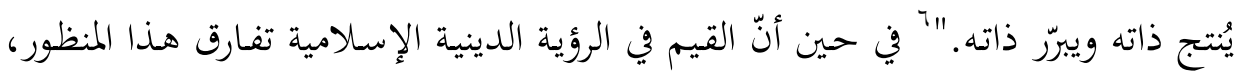

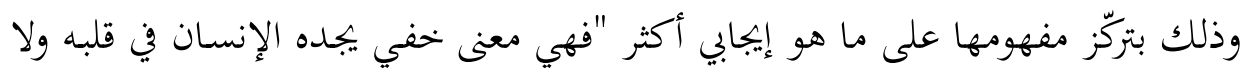

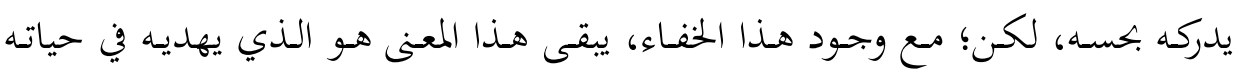

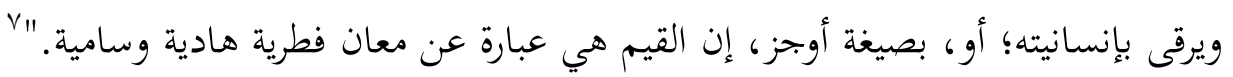

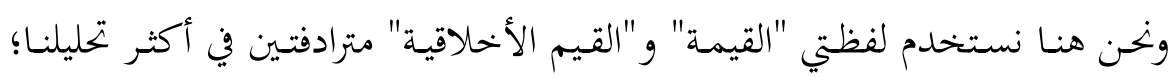

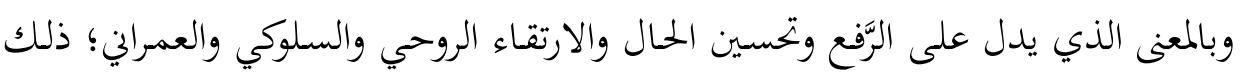

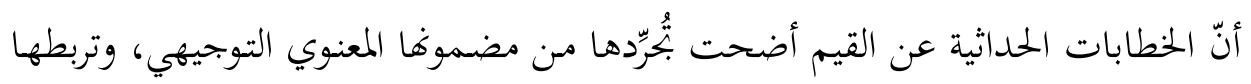

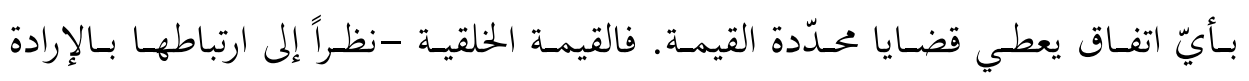
والتجربة في الفعل الإنساني - أضحت قناع تمرير لمقاصد متصادمة مع إنسانية الإنسية الإنسان.

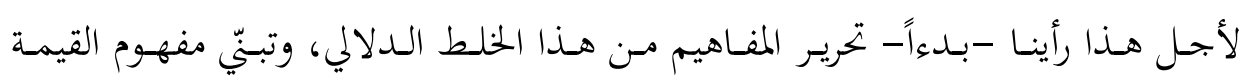

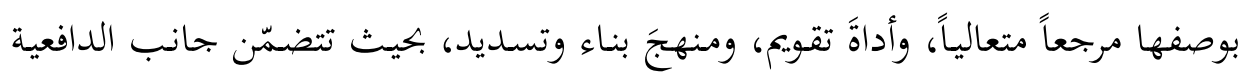

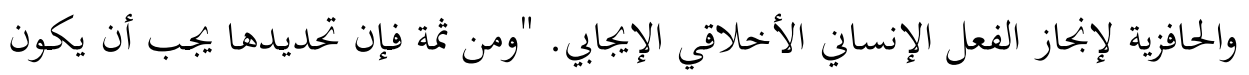

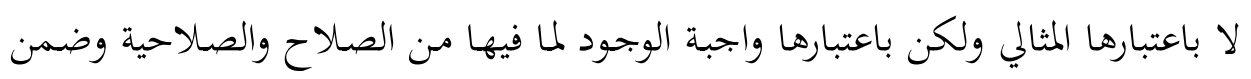

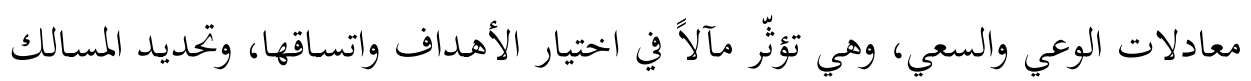

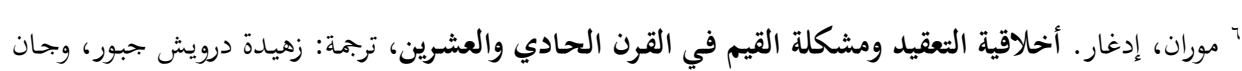

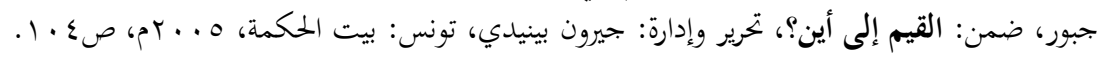

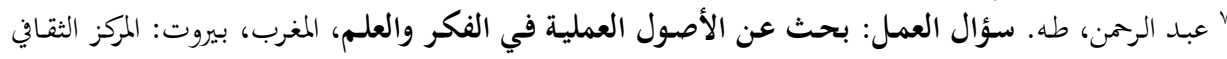


والأساليب والوسائل المتعلّقة بالفعل (بالتي هي أحسن)، وتتجسّد مظاهرها بالاتحاهات

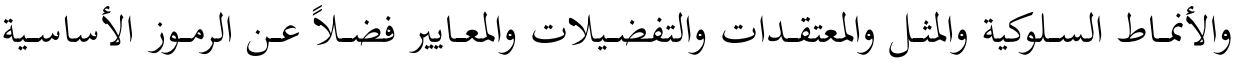

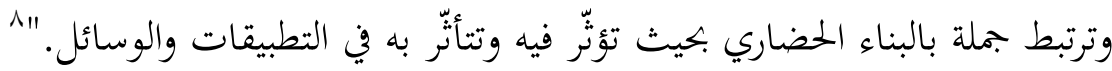

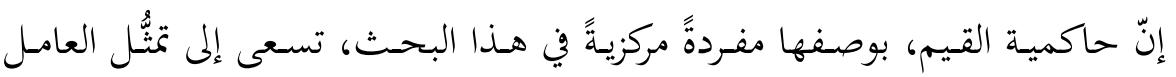

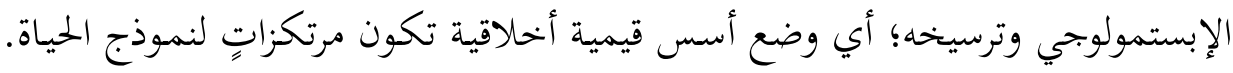

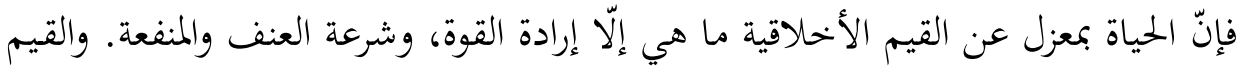

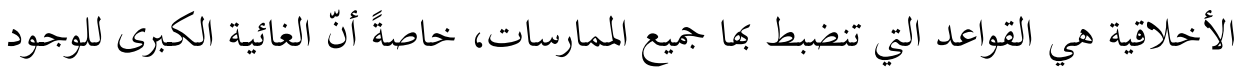

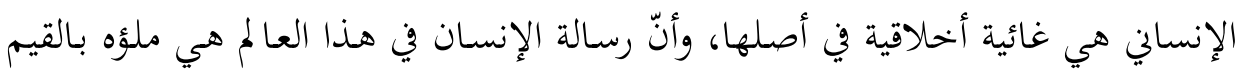

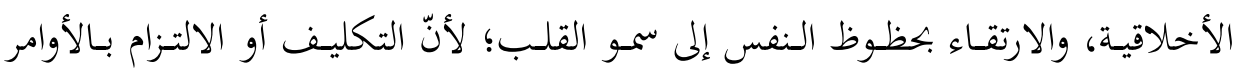

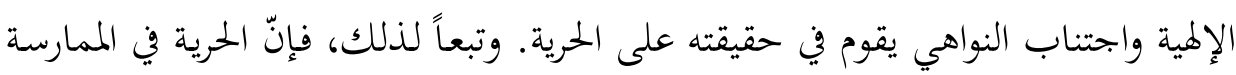

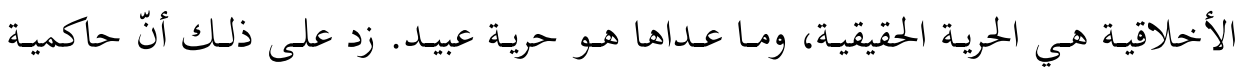

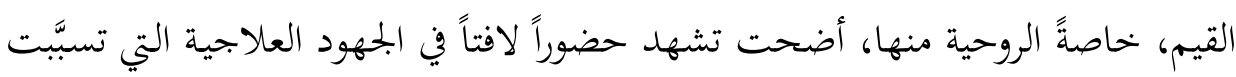

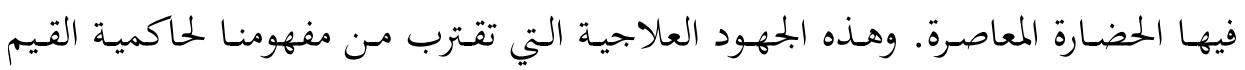
وركائزها الأساسية: - الحسارة المعاصرة

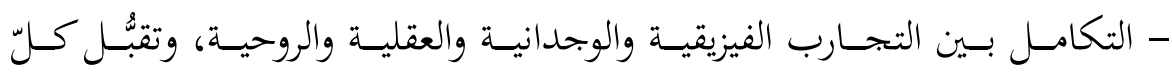

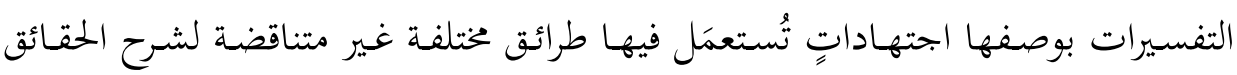
الفيزيائية، والبيولوجية، والذهنية، والروحية.

- التصوّر الغائي للحياة والتطور؛ إذ لا يُدرَكَ الواقع إلّا بوصفه كلّاُ واحداً. - وجود بُعْد روحي للحياة هو رمز الإنسانية.

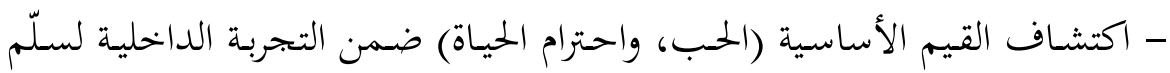
مستويات الوعي.

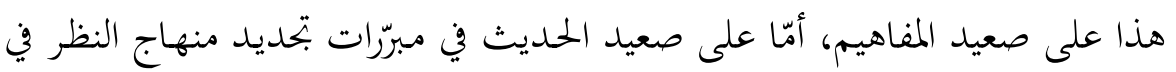

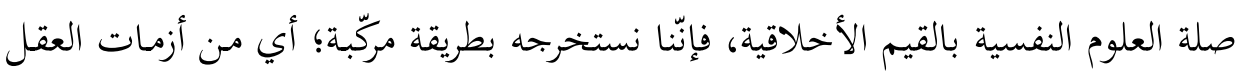

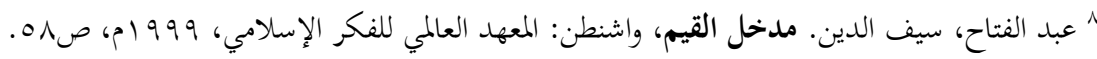

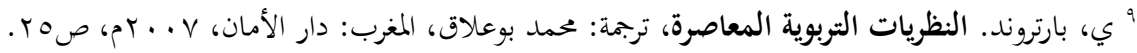




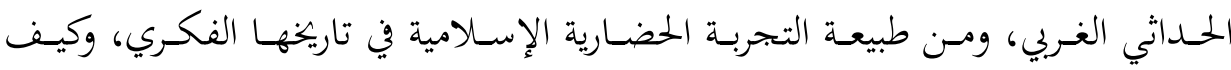

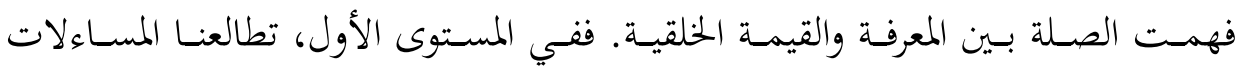

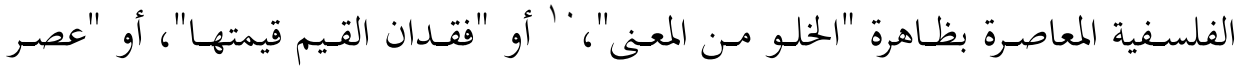

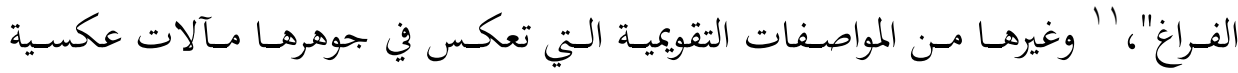
للطموح الحداثي الذي لازم حركة الحضارة الغربية، وهو طموح يتخذ من من السعادة والتقدّم

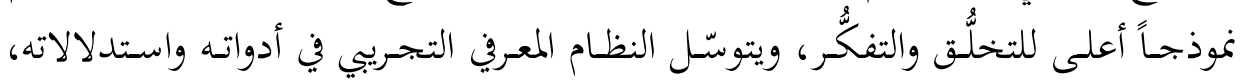

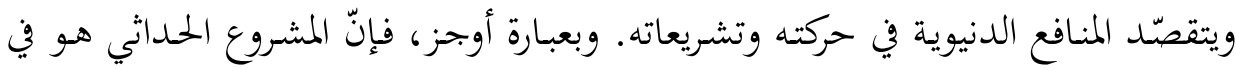
جوهره نظام في رؤية العالم، ونظام في المعرفة، ونظام في القيم. إذن، هي رؤيـة إلى العـا لم مبنيـة على إفراغـه مـن مضـامينه الدينيـة، وملئهه بالمضـامين

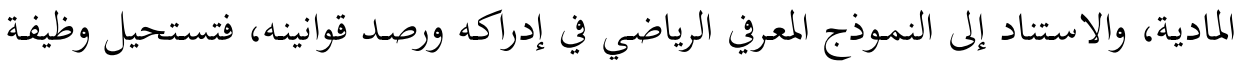

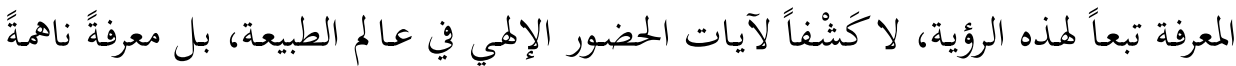

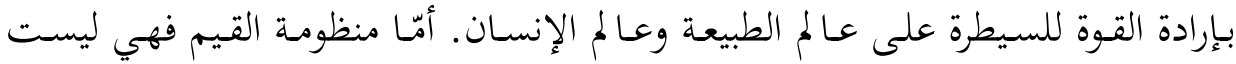

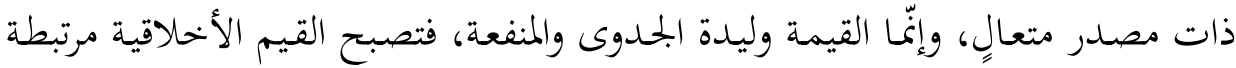
بمعيار المنفعة والقوة. وبهذا الاتساق بين ثنالوث رؤية العالم ونظام المعرفة ومنظومـة القيم

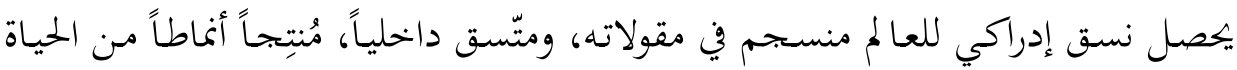

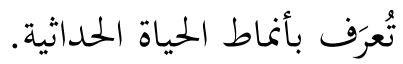
وهـذا المشــروع الحـــاثي الغـربي هـو المســؤول -معرفيـاً وحضــارياً- عـن التـأريخ لإبستمولوجيا الفصل بين نظام القيم الخلقية ودوائر المعرفة الأخرى، وفي مقدّمتها العلوم

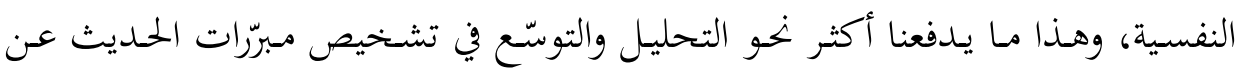

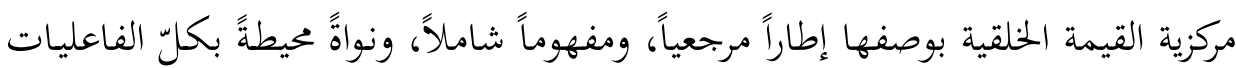
الإنسانية وغير الإنسـانية. ومـن المنحىى المنهجي، فإنّنـا نقسّم هذه المبرّرات إلى قسمين:

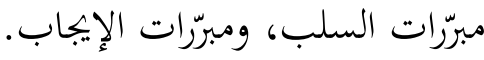

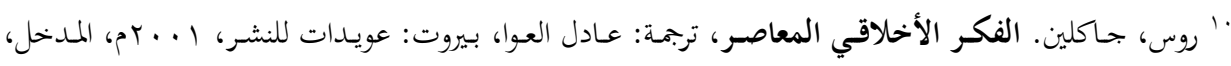
صa

${ }^{11}$ Gilles lipovetsky, l'ere du vide, Essai sur l'individualisme contemporaine, folio essais, paris, 1983. 


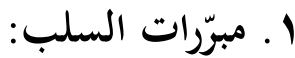

نقصد بمبرّرات السلب طبيعة المآلات العَدمية التي تُعَدّ نتائج سلبية في أفق الحداثة

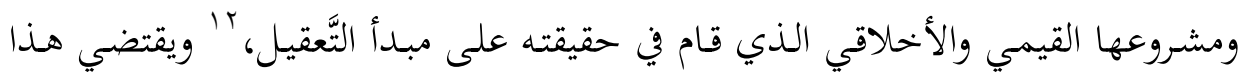

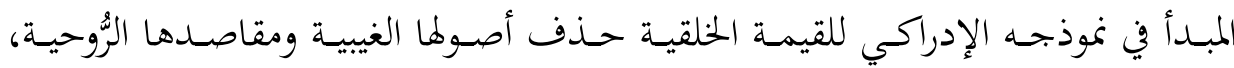

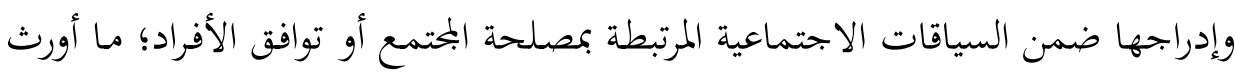

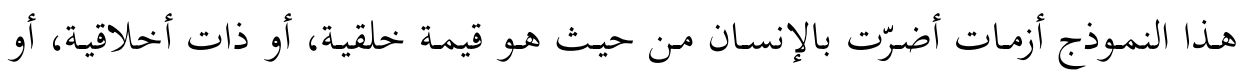

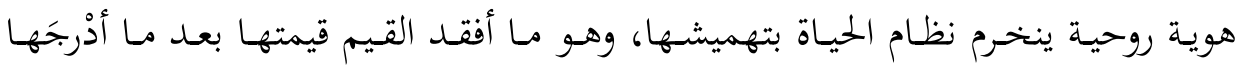
ضمن فلسفة النسبية والصيرورة.

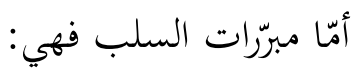

\section{أ. أثر الحداثة الانفصالية في منظومة القيم الأخلاقية:}

لقد أورثت الحداثة الغربية في مشروعها التعقيلي للقيم الأخلاقية، أزماتٍ غيرَ معهودة

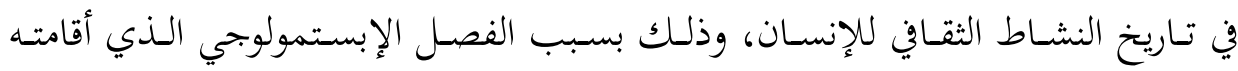

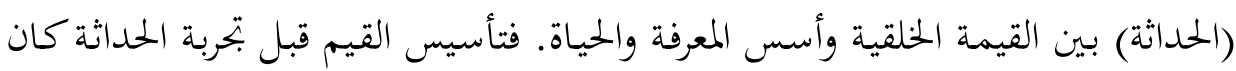

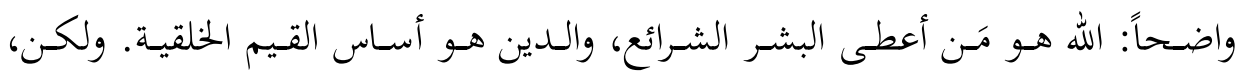

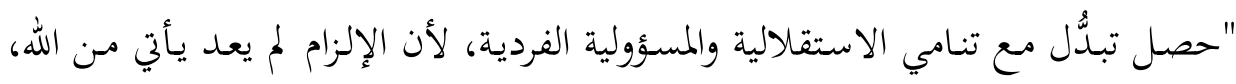

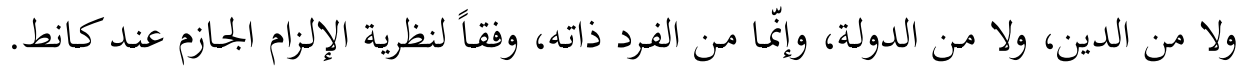

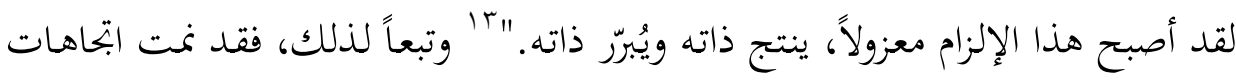

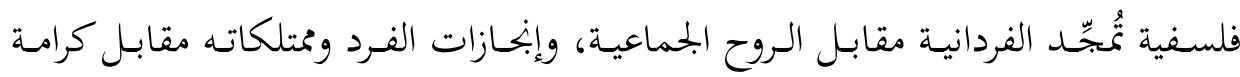

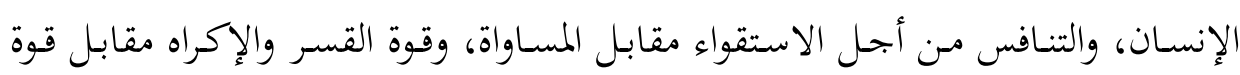

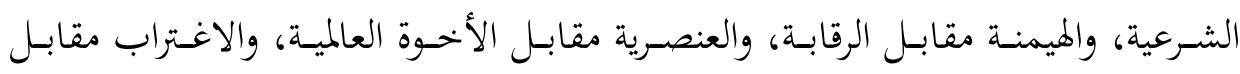

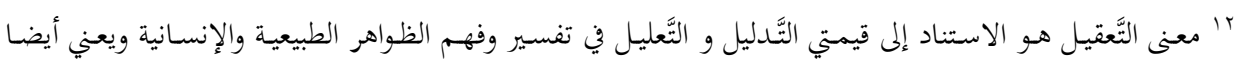

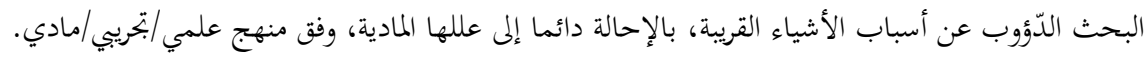

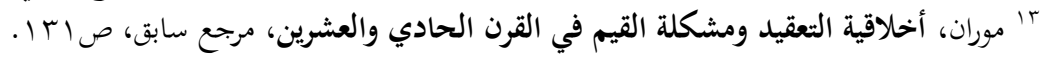


الانتماء، والسلوك والعقل مقابل الإيمان. ؛ُ إذّّا -لا شكُّ- مظاهر ونتائج لهذا الفصل

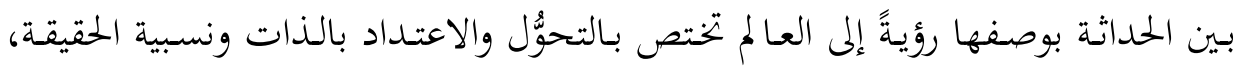

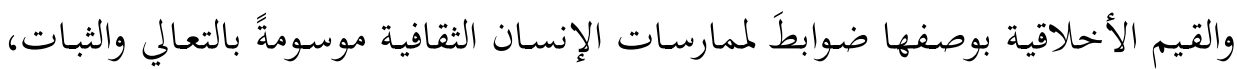

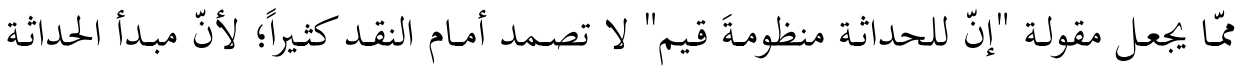
الفلسفي والأكسـيولوجي (القيمي) هـو تمجيــ للحريـة والفردانيـة، وخلق لقـيم جديـدة دائماً. ويمكن القول إنّ ما أحدثته الحداثة من انفصال في التاريخ الثقافي للإنسان يتمثَّل في الآتي: - 20 - n

- انفصـال الممارسـة العقليـة عـن القـيم، وتوريـث مـا يُسمّميه إدغــار مـوران منظومــة

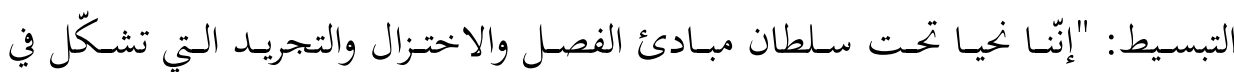

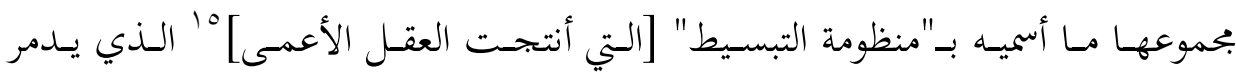

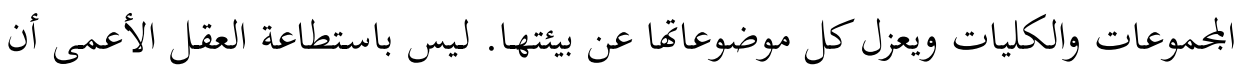

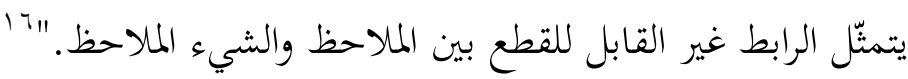
- انفصـال الممارسـة الإعلاميـة عـن الأخهلاق، وتوريـث السـلوك الغريـزي والإنسـان

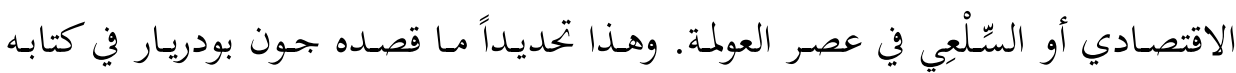
"المصطنع والاصطناع"، في أثناء تحليله قيمة المعنى في دوائر هيمنة وسائل الإعلام: "نحن

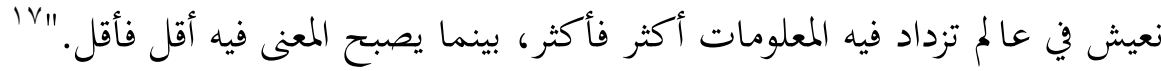
- انفصال الممارسة المعرفية عن الأخلاق، وتوريث النظرة الآلية والمادية للكون.

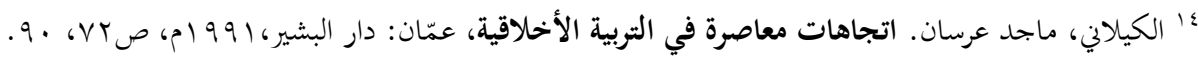

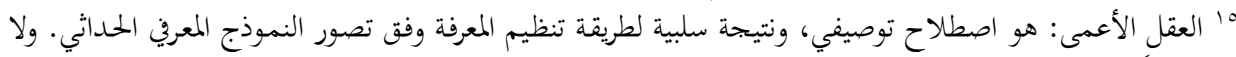

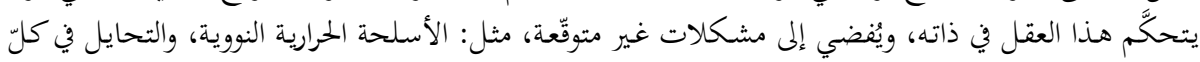

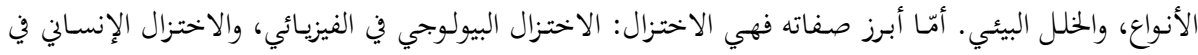
البيولوجي. موران، إدغار. الفكر والمستقبل: مدخل إلى الفكر المركّب، ترجمة: أحمد القصوار، ومنير الحجوجي، المغرب:

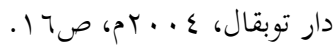

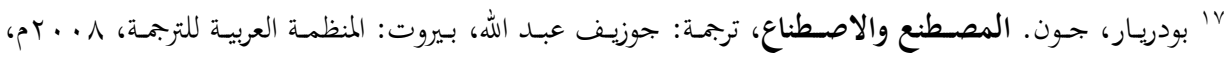




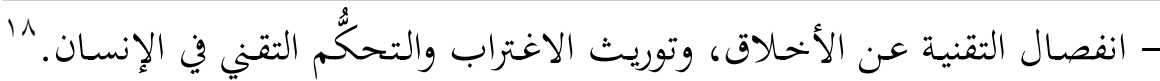

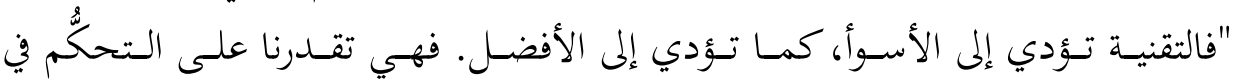

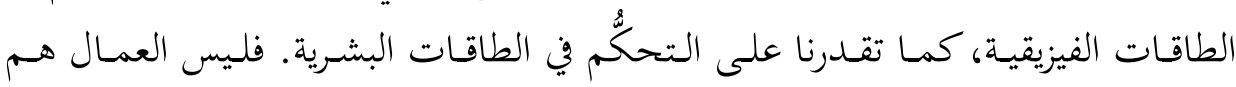
وحدهم الذين سخّروا لمهام تكرارية ومقننة، بل إن بحموع المحتمع قد أخضع لمنطق الآلة الاصـطناعية، القائمــة على العقلنـة وعلى التوقيـت المفـرط للـزمن، بمـا أدى إلى رد فعـل

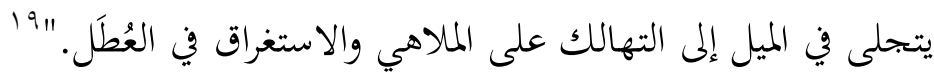

يتبيَّن ممّا سبق كيف انعكست بتربة الحداثة على منظومة القيم الأخلاقية انعكاساً

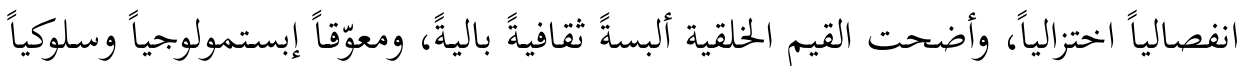
لحرية إنسانية أصبحت مقدّسة ضمن جداول قيم الإنسان الحديث.

\section{ب. الؤية التجزيئية للقيم الأخلاقية ضمن نظريات القيمة المعاصرة:}

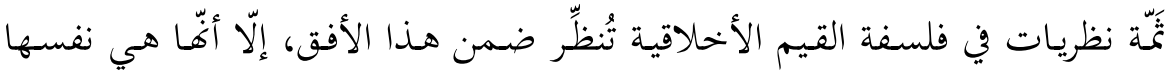

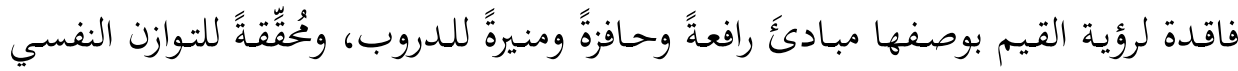

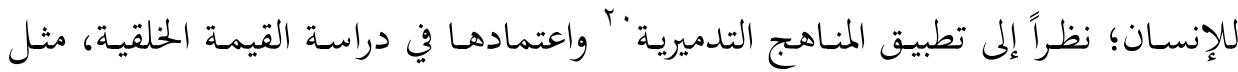

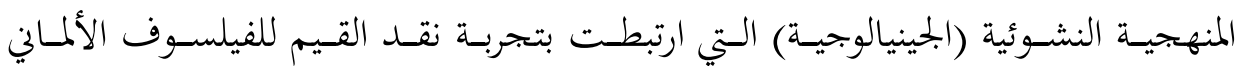

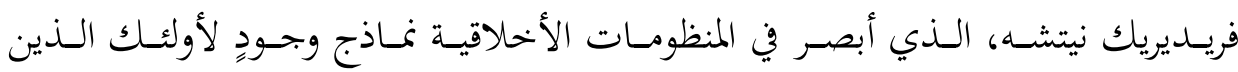
يهكمون ويُقيِّمون، ودعا إلى إعادة ترتيب القيم الأخلاقية خارج الموروث الأخلاقي الذي يُمجّد قيم الضعف والنفي. وبالرغم من الملمح الإيجابي لنيتشه المُتمثّل في إدراكه مركزية 11

- بلعقروز، عبد الرزاق. المساءلة النقدية للحداثة والعولمة في مشروع طه عبد الرحمن الفلسفي، قسنطينة:

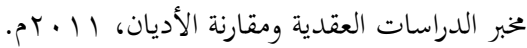

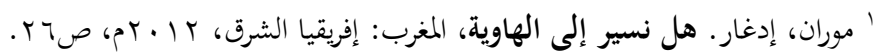

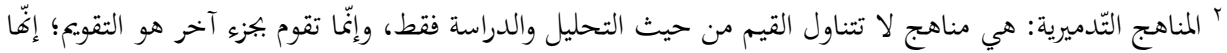

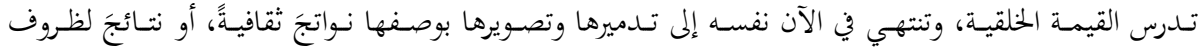

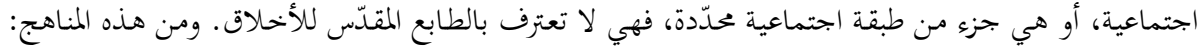

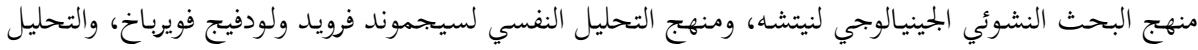




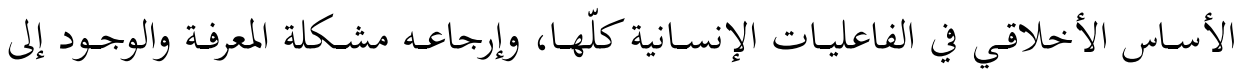

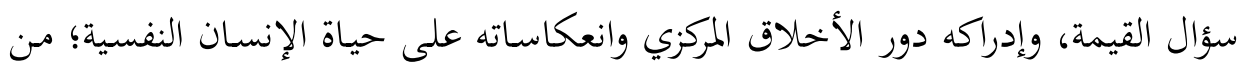

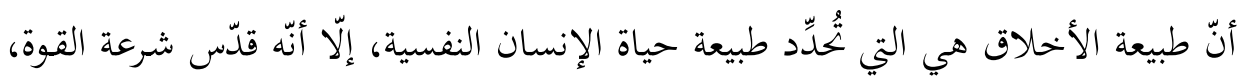

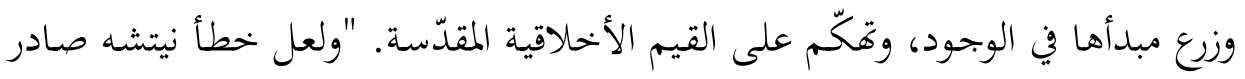

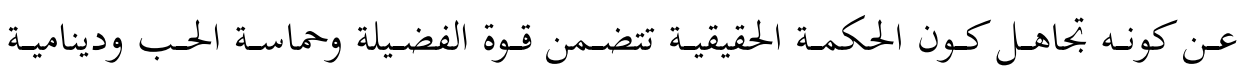

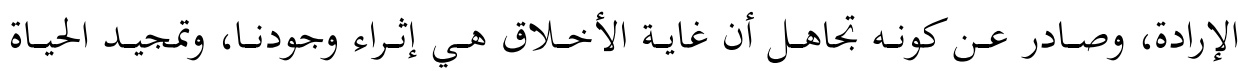

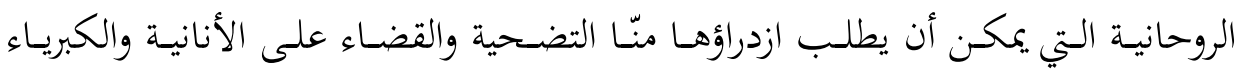

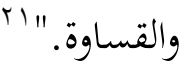

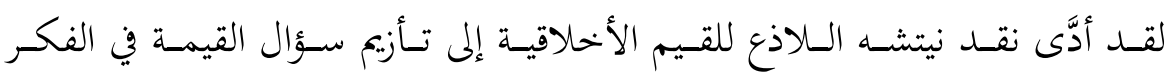

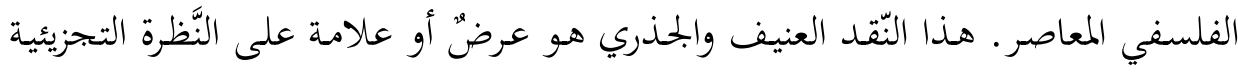

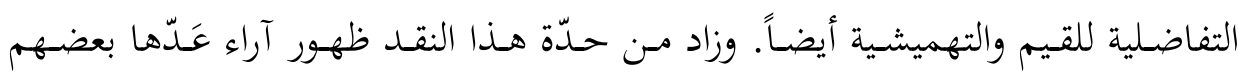

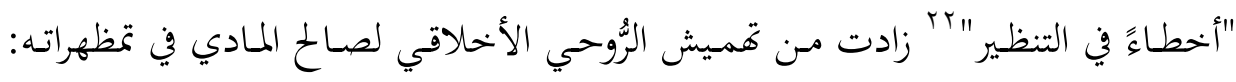

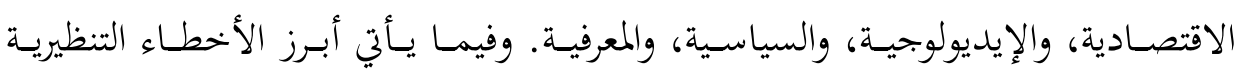

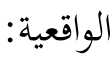
- نـزع القداسـة عـن القيم: وذلك بإسكاها في النسبية، والظروف، والسياقات

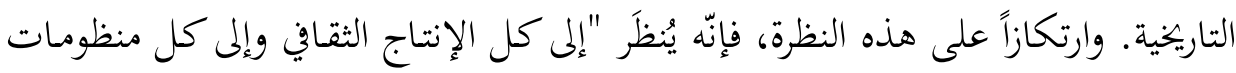

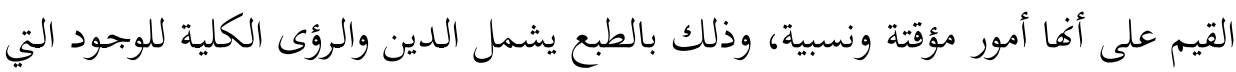

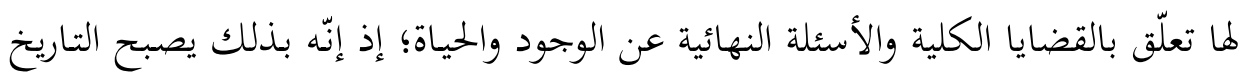

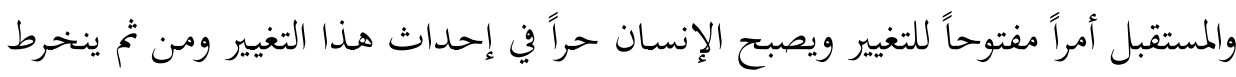

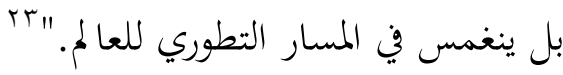

" ميمون، الربيع. نظرية القيم في الفكر المعاصر بين النسبية والمطلقية، الجزائر: الشركة الوطنية للنشر والتوزيع،

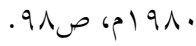

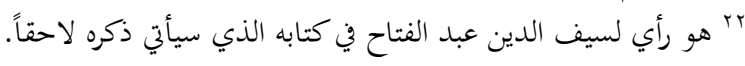

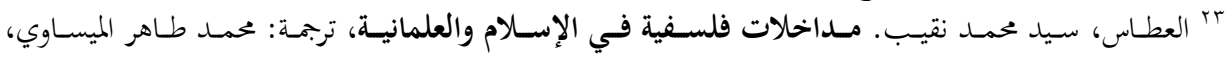

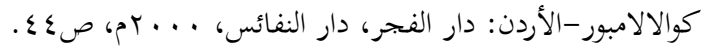




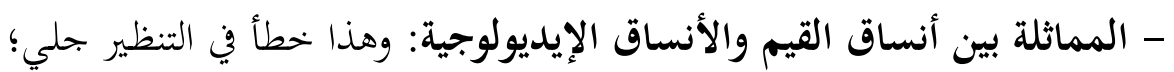

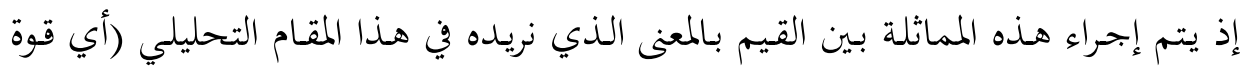

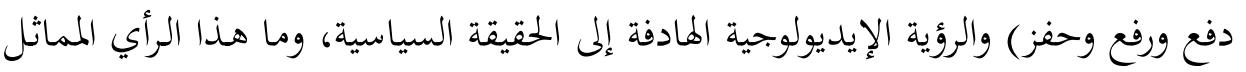

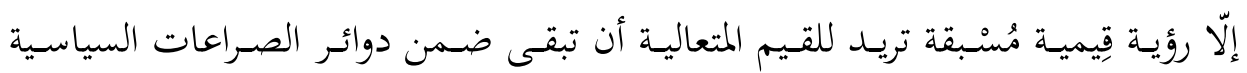

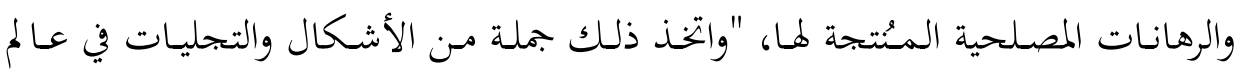

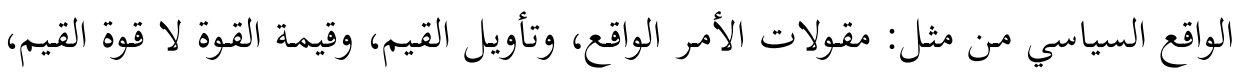

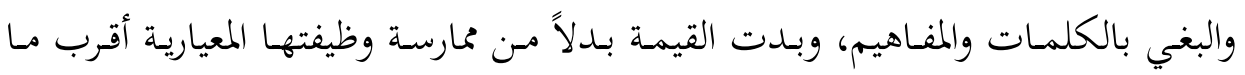

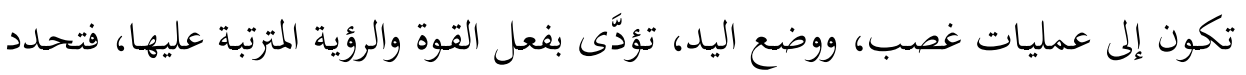

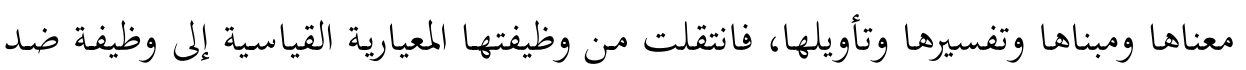

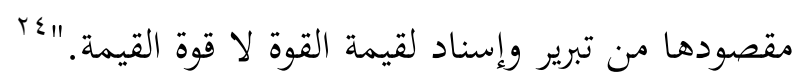

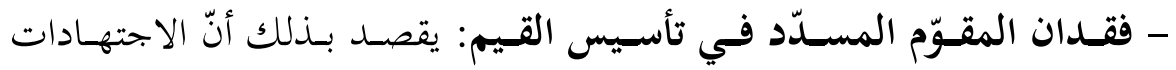

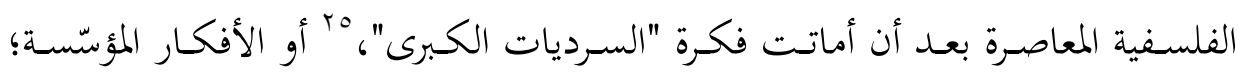

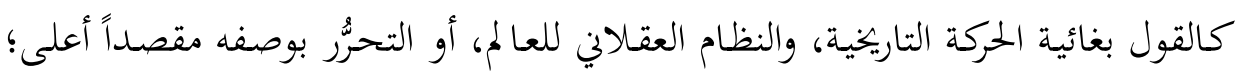

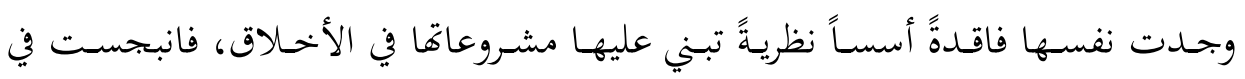

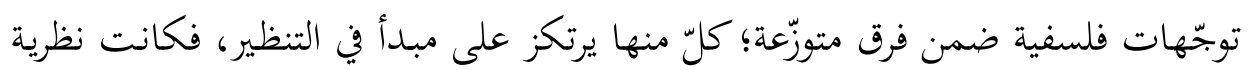

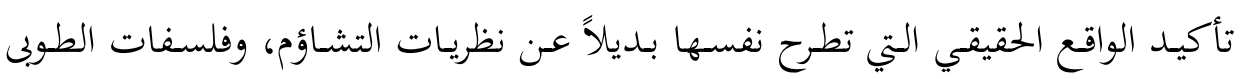

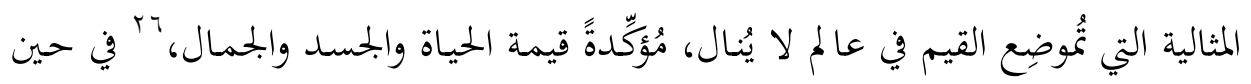

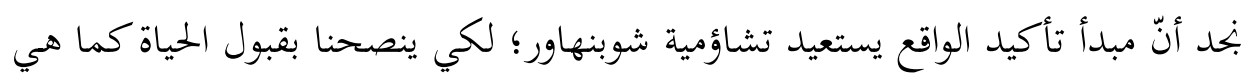

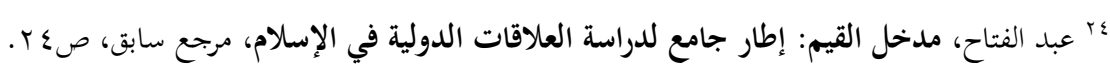

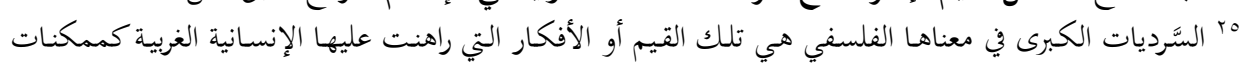

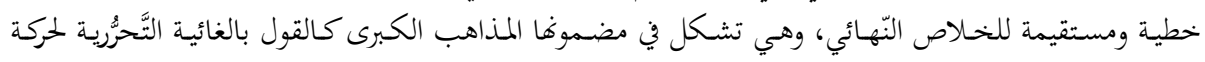

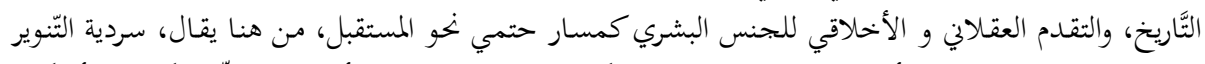

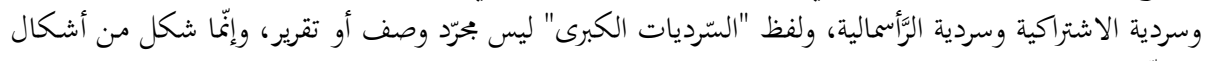

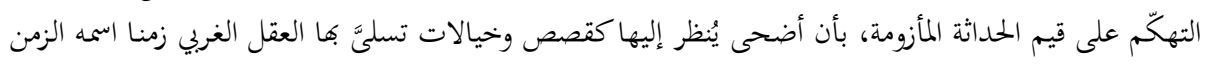




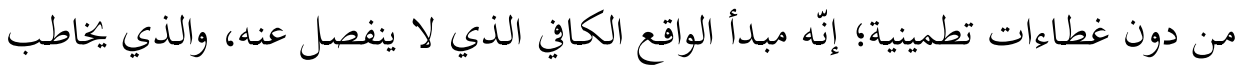

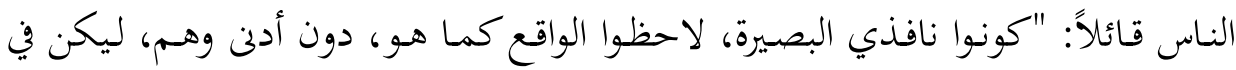

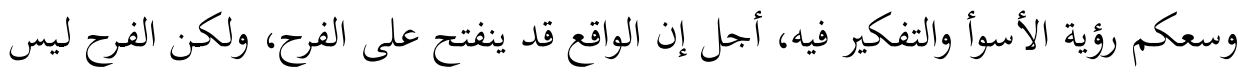

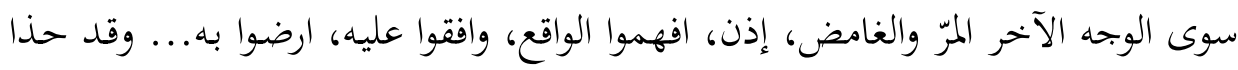

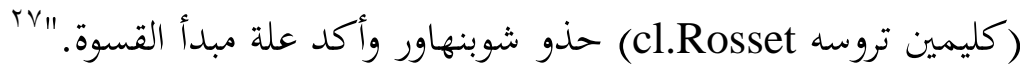

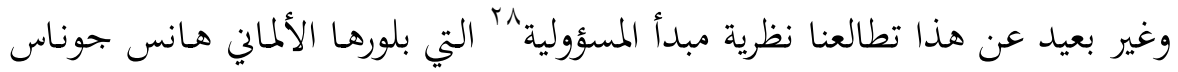

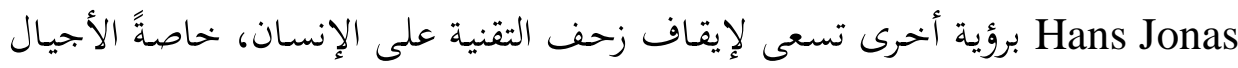

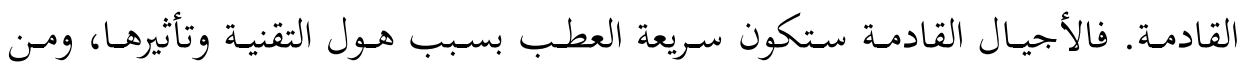

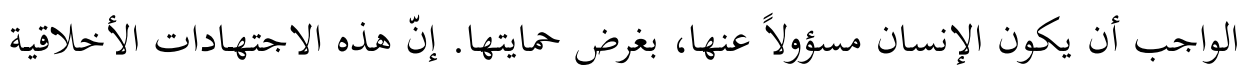

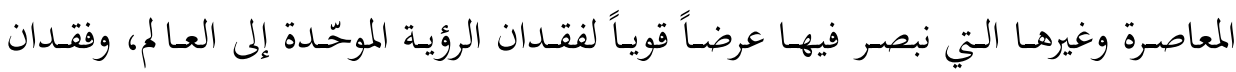

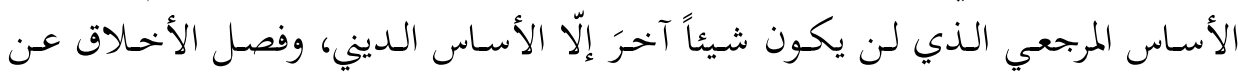

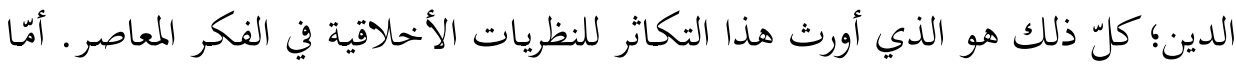

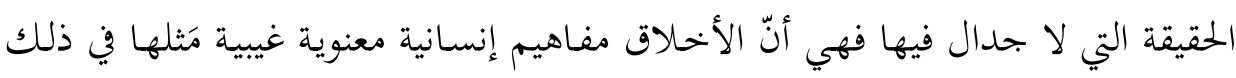

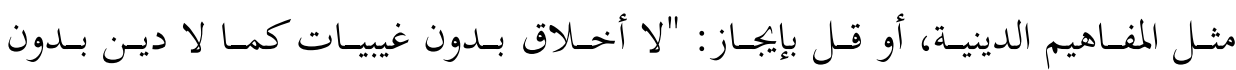

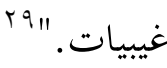

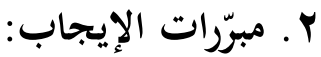

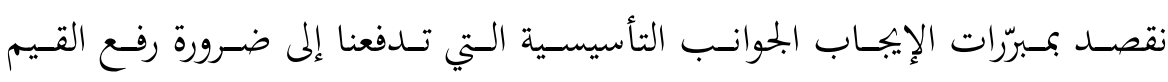

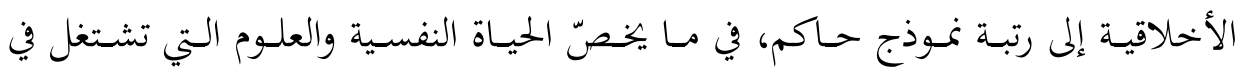

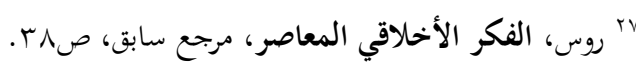

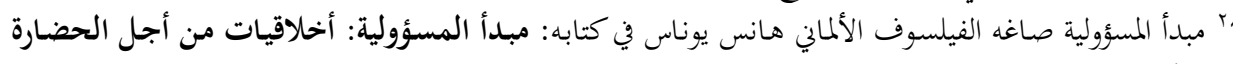

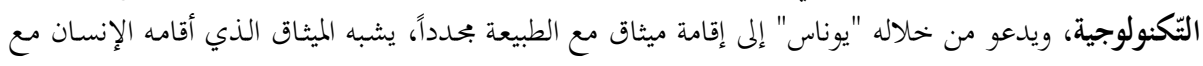

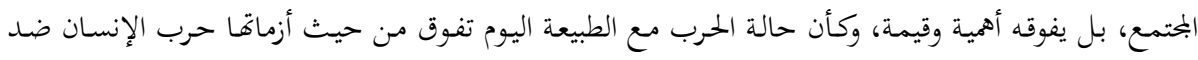

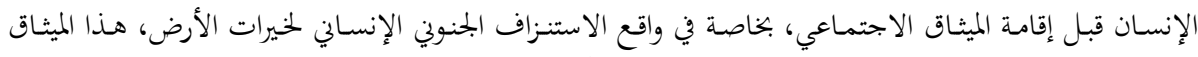

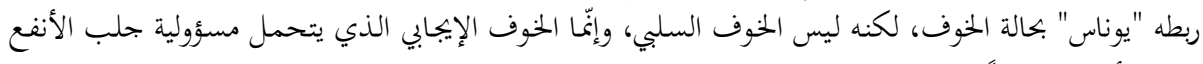
ودفع الأفسد حفاظاً على البيئة. ج9 عبد الرمن، طه. سؤال الأخلاق: مساهمة في النقد الأخلاقي للحداثة الغربية، المغرب: المركز الثقافي العربي، 


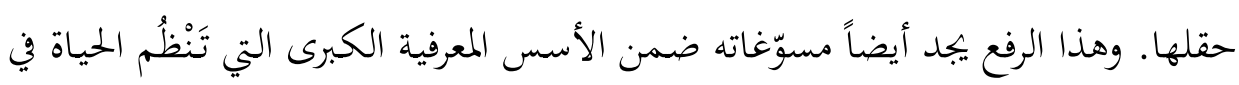

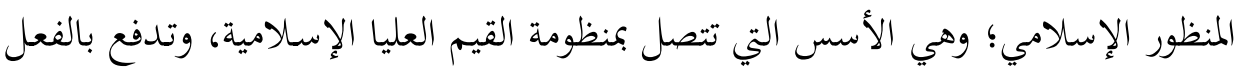

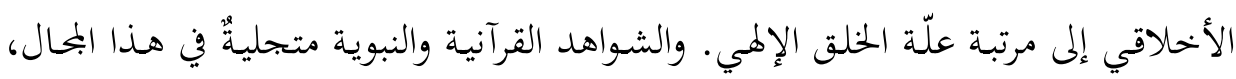

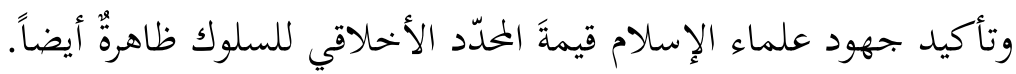
أمّا الأسس الإيجابية التي تؤّدّد مركزية الفعل الأخلاقي في الرؤية الإسلامية فنتلمّسها

\section{الإطار المرجعي لمنظومة القيم في الرؤية الإسلامية:}

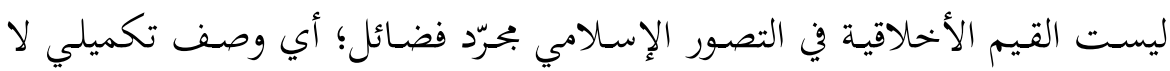

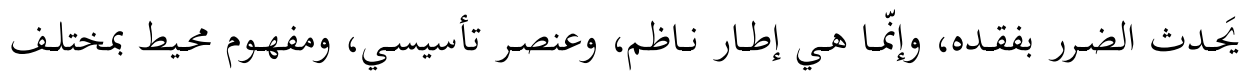

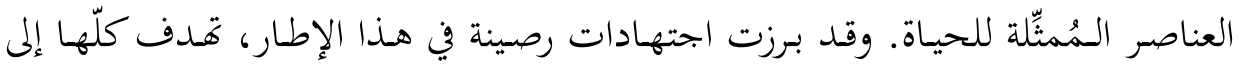

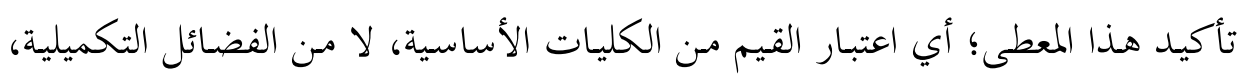

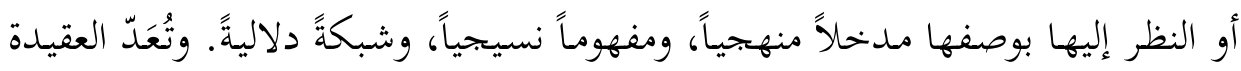

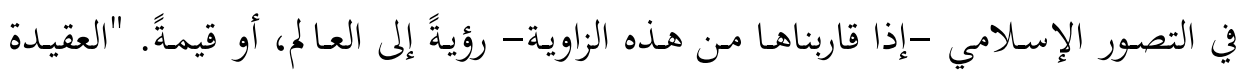

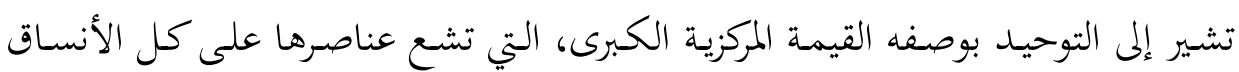

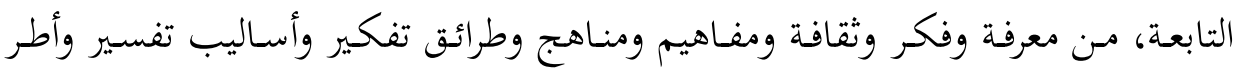

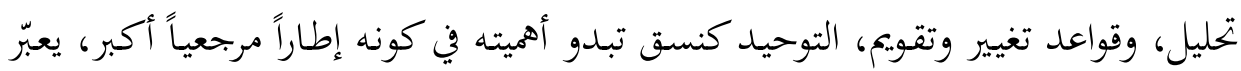

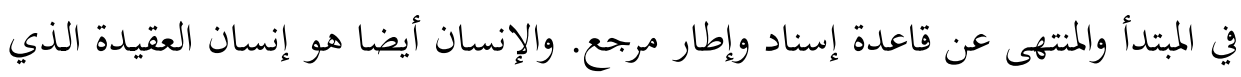

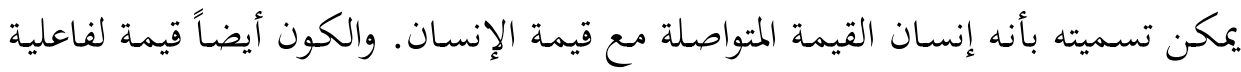

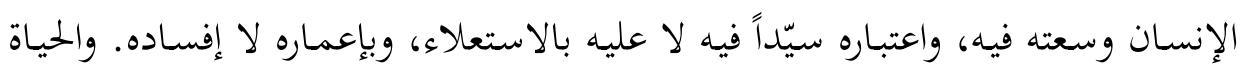

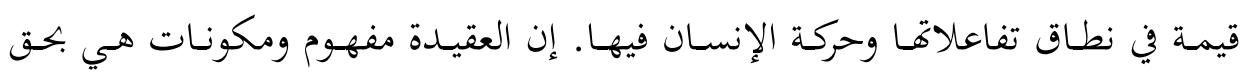

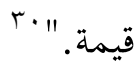

جلي، إذن، هـذا التضـمين الكلي للقيمة ضـمن المبـدأ الأول والنواة الأولى للنسيج

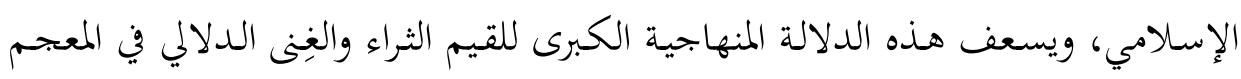

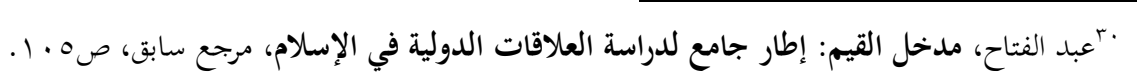




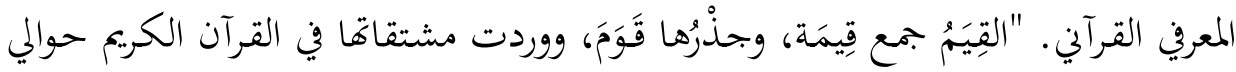

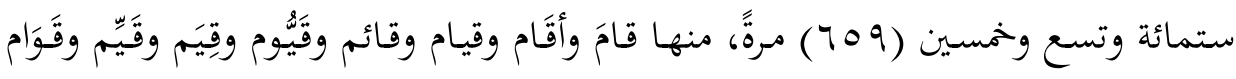

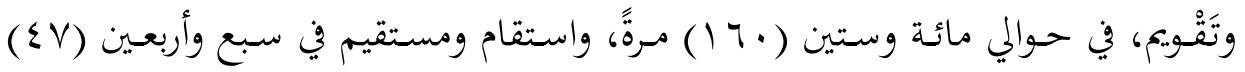

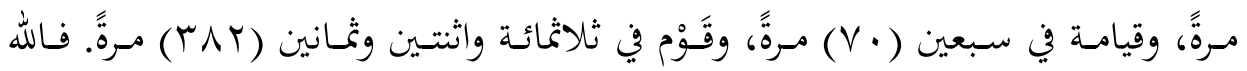

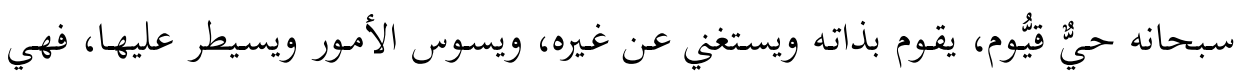

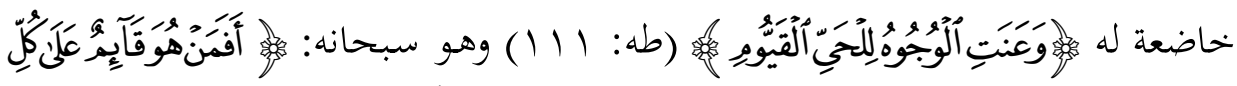

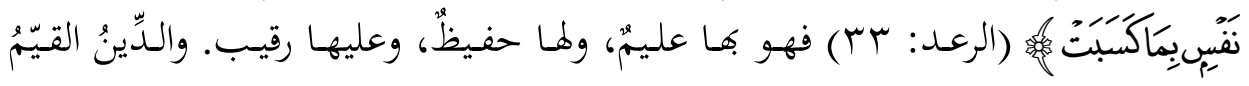

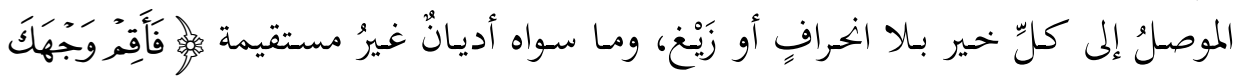

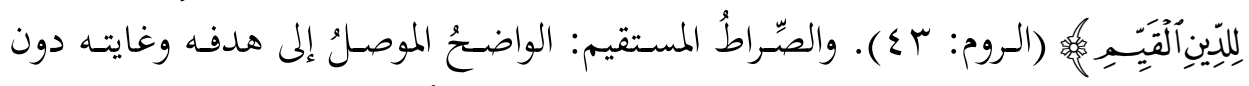

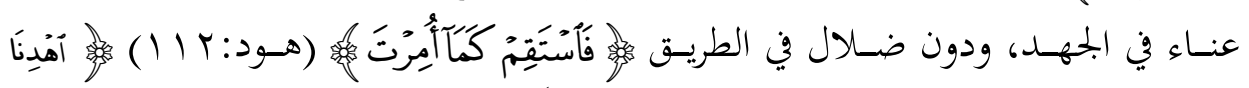

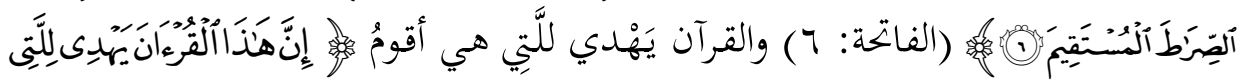

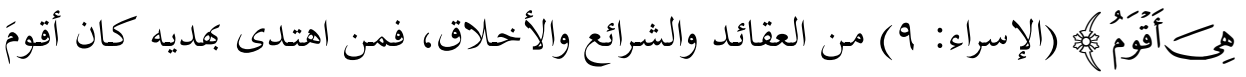

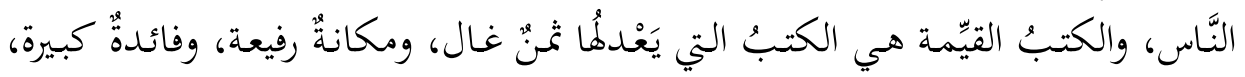

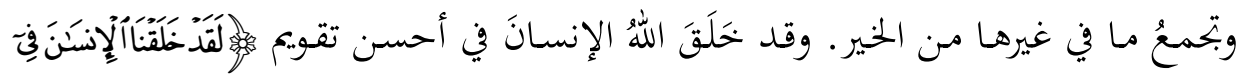

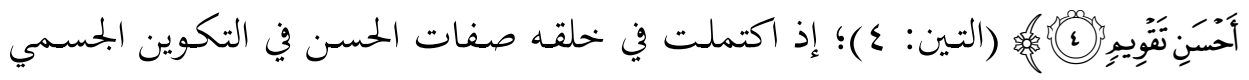

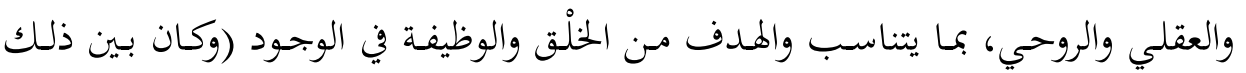

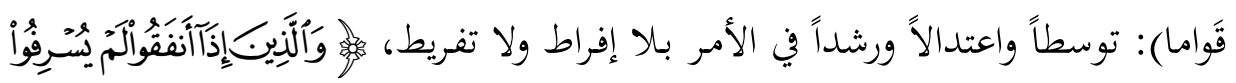

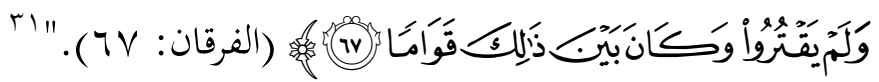

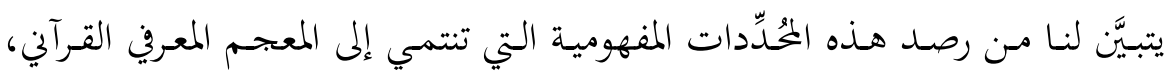

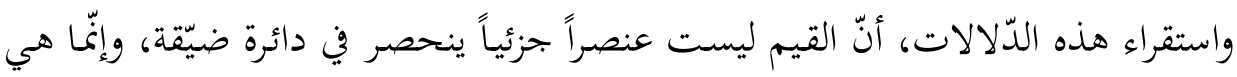

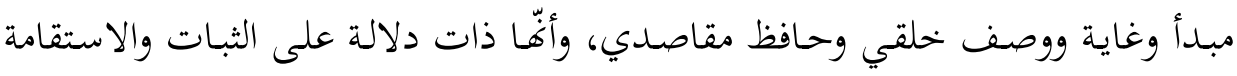

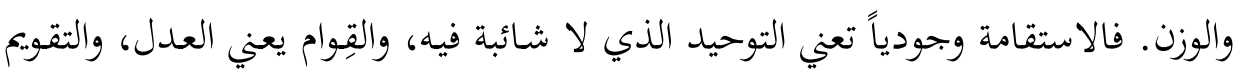

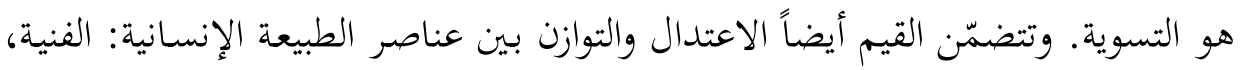

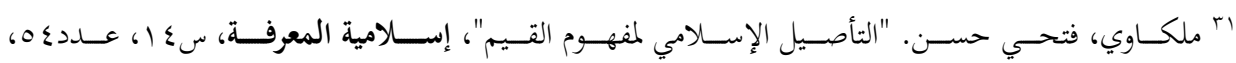

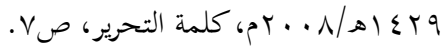


والعلمية، والعملية، وكذلك التوازن بين الفرد والجماعة، وبين الثبات والتطور، وبين المرونة

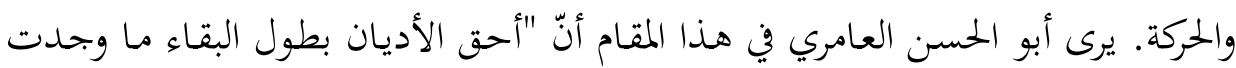

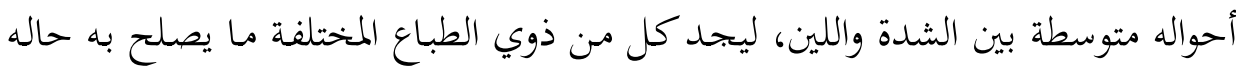

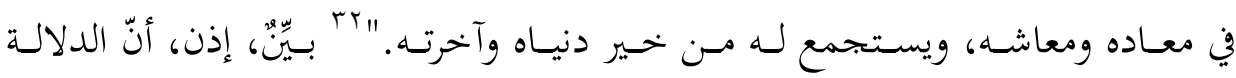

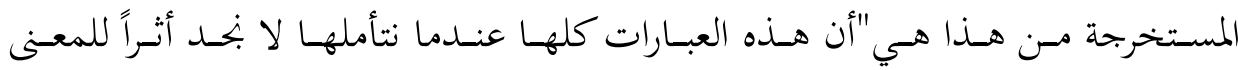

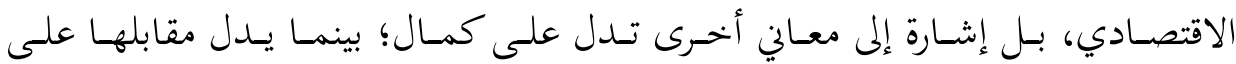

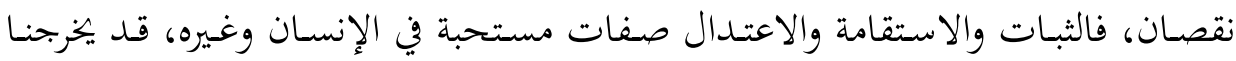

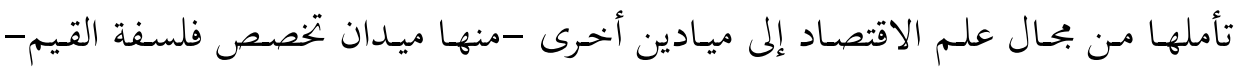

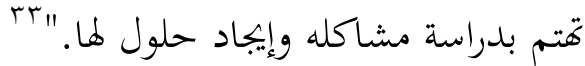

إنّ اللفتة الاستقرائية التي أشرنا إليها من القرآن الكريم، والتي تتسع فيها دلالة القيم اشتقاقاً إلى بحالات الحياة كلّها؛ تعكس المنزلة المركزية للقيم الحاكمة، وبيان ذلك كالآتي: - إنّ "جماع المعاني اللغوية في أصولما القرآنية تشير إلى أن الكون كله قائم على نظام

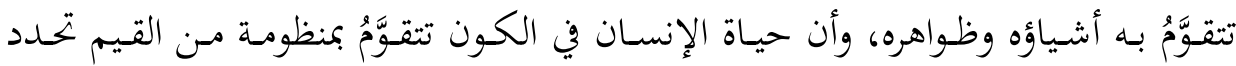

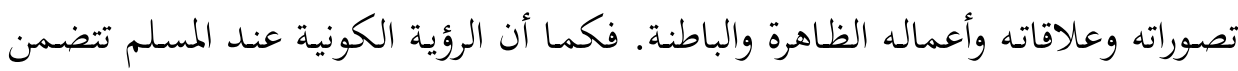

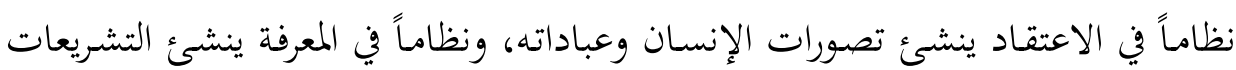
والعلاقات، فكذلك تتضمن هذه الرؤية نظاماً للقيم تتحدد به دوافع السلوك والعمل. نظام الإسلام= نظام الاعتقاد + نظام المعرفة + نظام القيم."

- إنّ السعة المفهوية والاشتقاقية التي يُوفِّهـا النص القرآي ينقلها من الوجود المثالي إلى الوجود الفعلي الحركي، وذلك لارتباطها القوي بالاستقامة العملية، عن طريق كفّ تهرئ

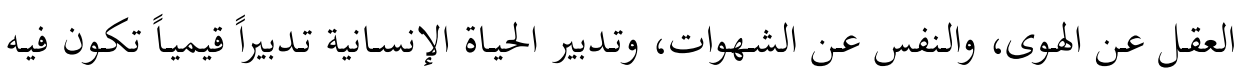

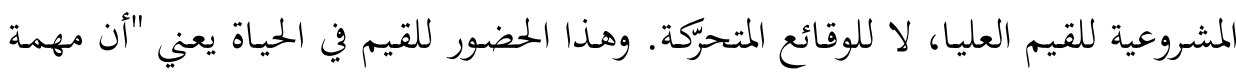
rrr انظر: العامري، أبو الحسن. الإعلام بمناقب الإسلام، تحقيق: أحمد غراب، الرياض: دار الأصالة للثقافة والنشر

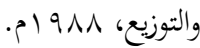

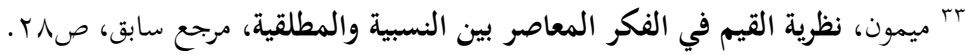

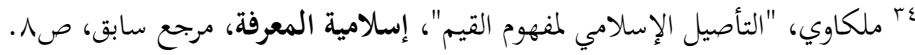


القرآن الكتاب الذي يشمل المثالية الإسـلامية في كمالاتها هي مهمة قيميـة بالأسـاس، فهناك مهمة أساسية عملية بحدها في قوله تعالى "إن هذا القرآن يهدي للتي هي أقوم". ومهمـة القـرآن هدايـة تقـوم على نظـام عملي يصـوغ حيـاة طيبـة تليـق بآدميـة الإنسـان

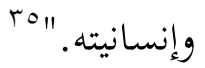

وتأسيساً على ذلك، يمكن اعتبـار القيم إطاراً مرجعياً، ومنظومةً تأسيسيةً، أو أَّّا

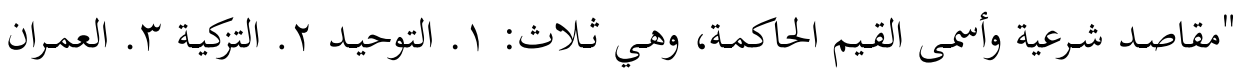

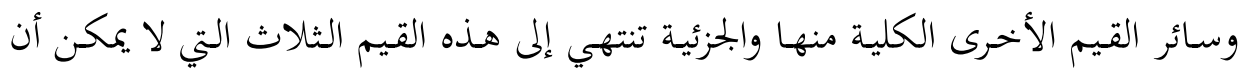
ينفصل أي منها عن الآخرين؛ فالتوحيد غاية التزكية وهـدفها، ووسيلتها في الوقت ذاته.

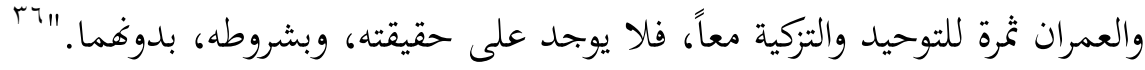
وتمَّة اجتهادات تصنيفية أخرى للقيم ترتكز أيضاً على هذا الإطار المرجعي في القيم؟

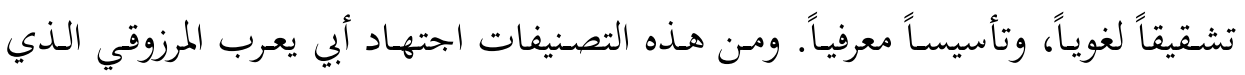
رفض التقسيم الثلاثي، وعَدّ مَن يتشبّثث به حبيس التثليث الديني الذي تختص به الديانة المسـيحية والفلسـفات المنبثقــة منهـا. لقــ طوّر المرزوقي خماسيةً أخـرى لا تـرفض القـيم

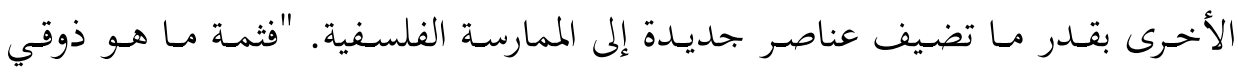
(يخص كـل الفنـون الجميلـة بقيمتي الجميـل والـدميم)، ومنـه مـا هـو رزقي (يخص كـل الأخيار بقيمتي النافع والضار أو الخير والشـر لبقاء الجمسد)، ومنه مـا هو نظري (يخص إنص كل المعارف والخبرات بقيمتي الصدق والكذب إخباراً عن المدركات)، ومنه ما هو عملي (يخص كل الأعمال التي تتعلق بالسلطة أو القدرة على الفعل بقيمتي الحرية والعبودية أو حريـة الاختيـار والاضطرار)، ومنـه مـا هـو وجـودي مـا بعـد طبيعي كـان (ومنـه النـزوع

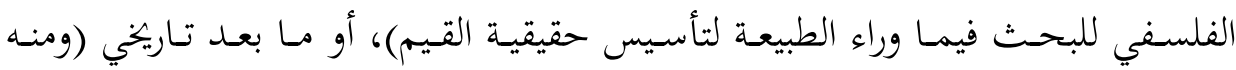
النزوع الديني للبحث فيما بعد التاريخ لتأسيس قيمة الحقائق)."VV"

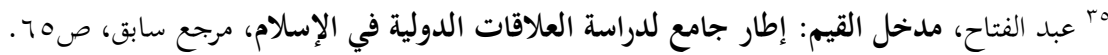

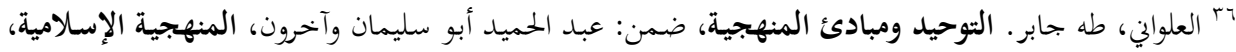

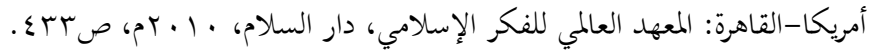

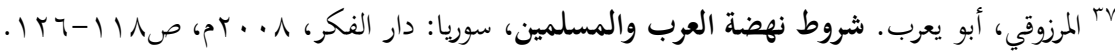




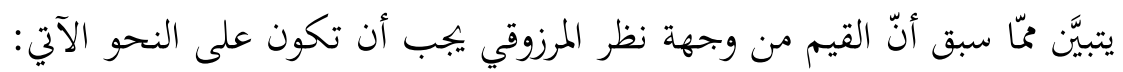

القيمـة الذوقيـة (جميـل قبـيح)، القيمـة الرزقيـة (خـير شـر)، القيمـة المعرفيـة (صـدق

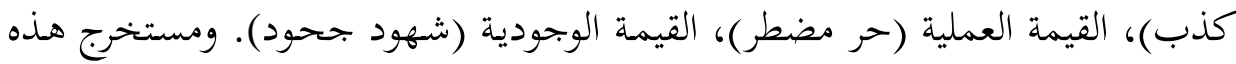

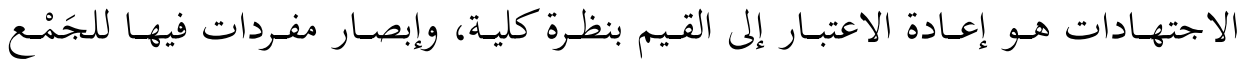
والتنظير والتأسيس، وكذلك الإحاطة بمختلف جوانب الفاعليات الإنسانية: الإيمانية،

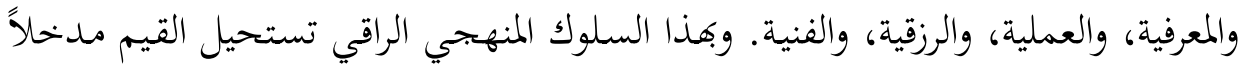
منهاجياً ركيناً في فعل التشريع لمنظومة السلوك المستقبلية.

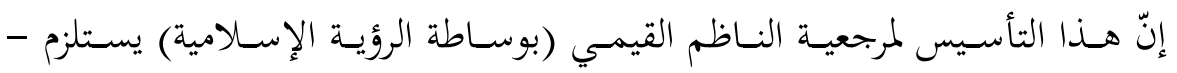

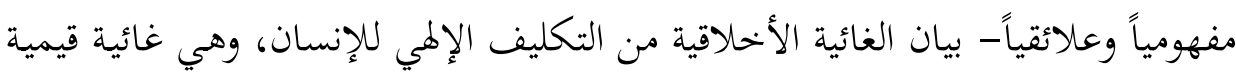

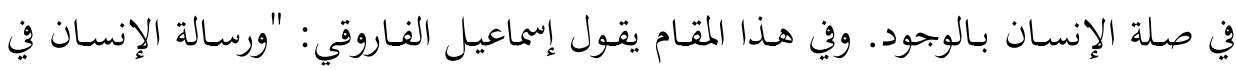

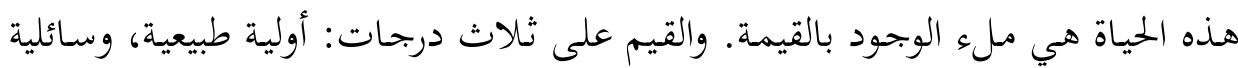

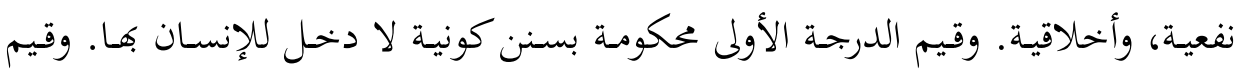

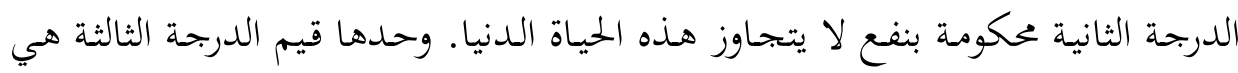

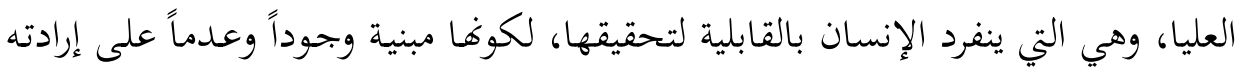

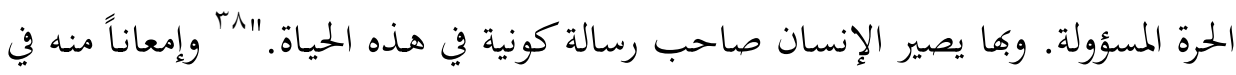

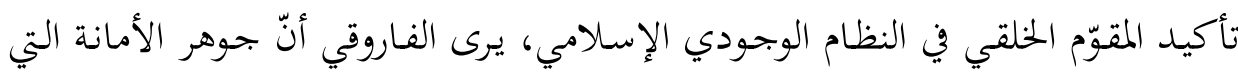

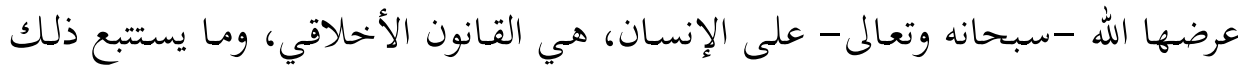

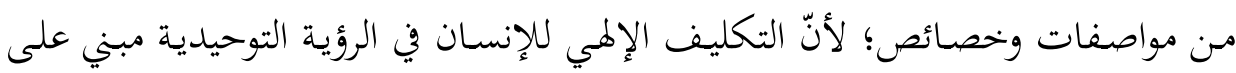

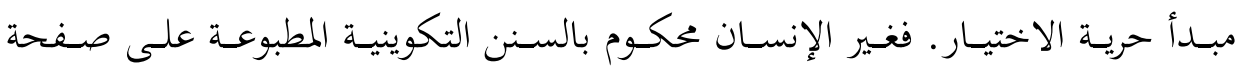

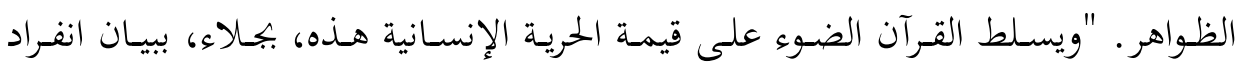

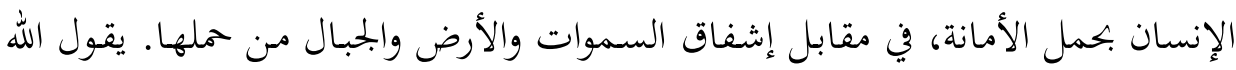
^^ الفاروقي، إنماعيل راجي. التوحيد: مضامينه على الفكر والحياة، ترجمة: السيد عمر، صل (نسخة إلكترونية). - www.4shared.com/document/btqVrhvS/__.htm

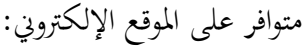




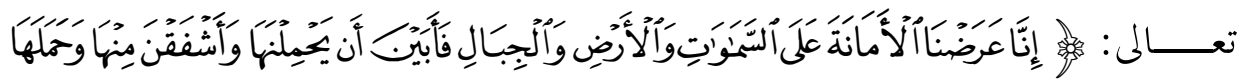

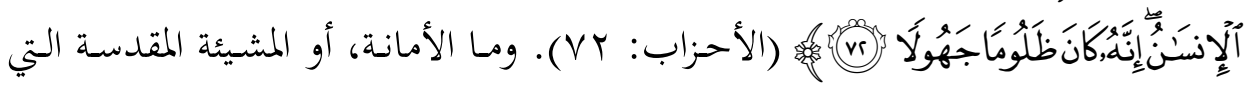

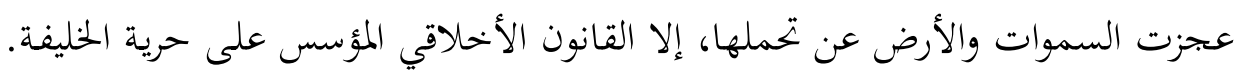

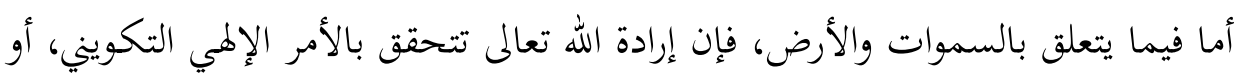

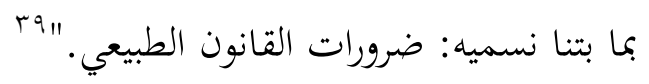

واللافت للنظر هنـا هو أسبقية القيمة الخلقية على غيرهـا مـ القيم، فهي متصلة

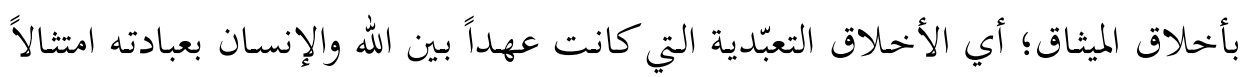

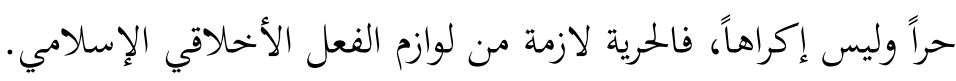

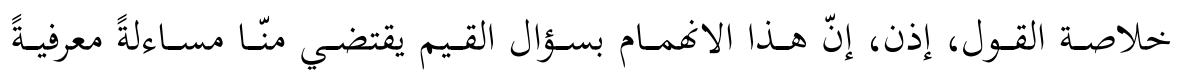

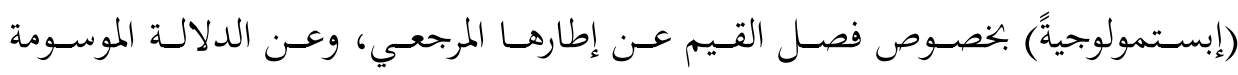

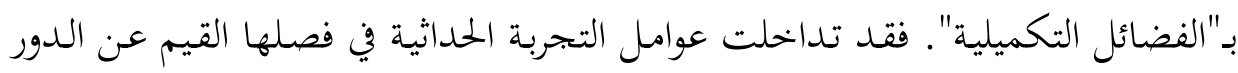

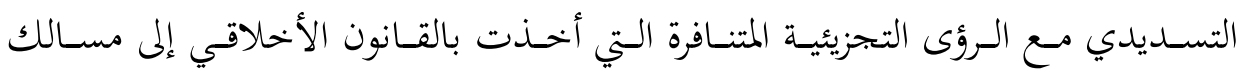

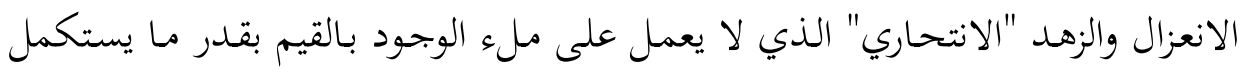

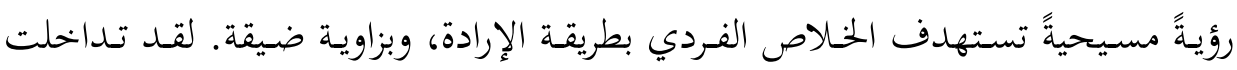

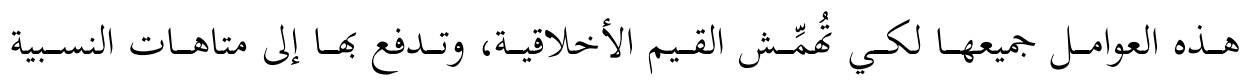

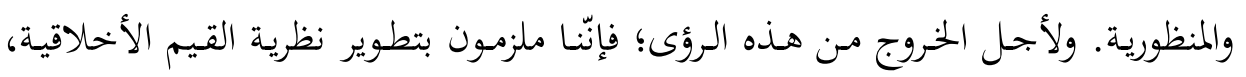

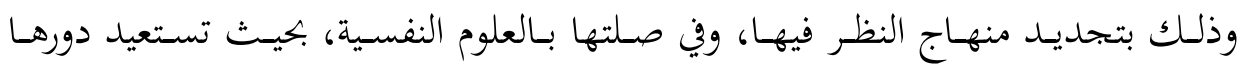

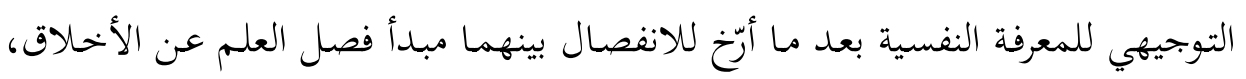

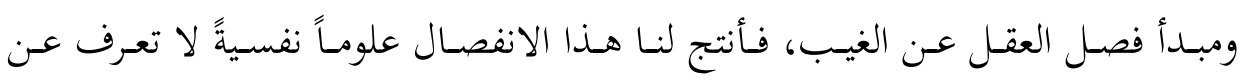

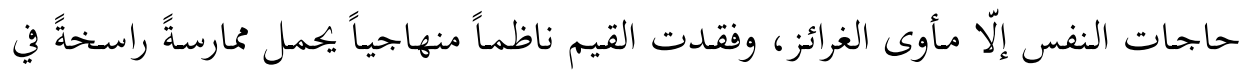

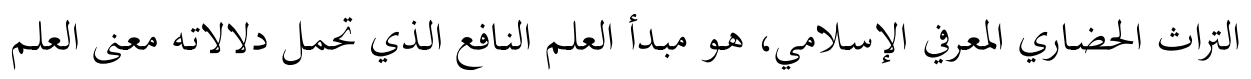

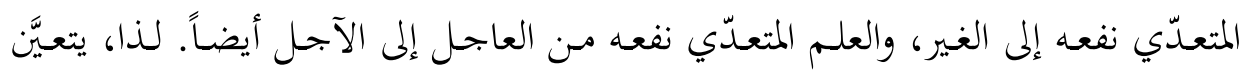

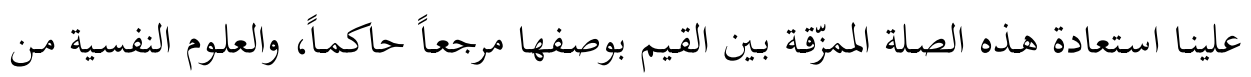




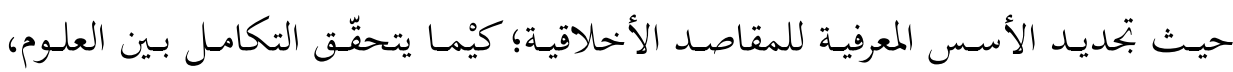

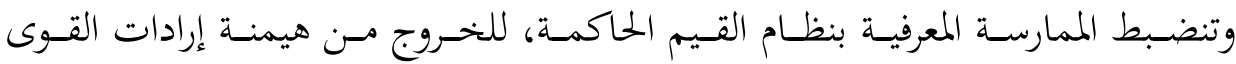
السياسية والاقتصادية، والسكنى في سعة القيمة، وإبحاز المهمة الاستخلافية للإنسان.

\section{ثانياً: إبستمولوجيا الفصل وانعكاساتها على العلوم النفسية}

لم تقتصر هذه الإبستمولوجيا على الفصل بين القيمة الأخلاقية وفهم حياة الإنسان

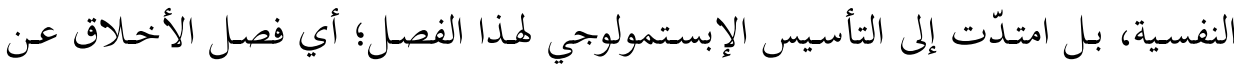

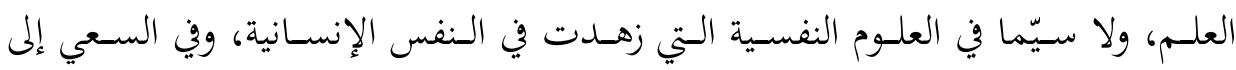

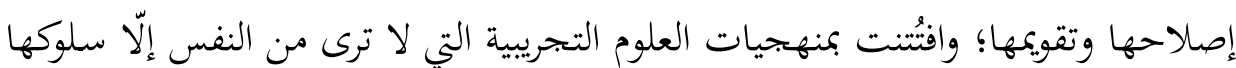

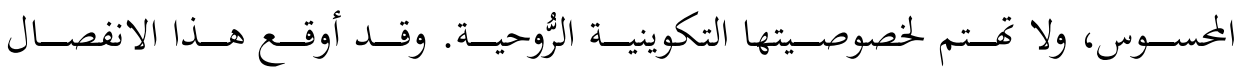

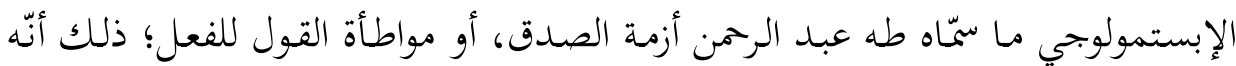

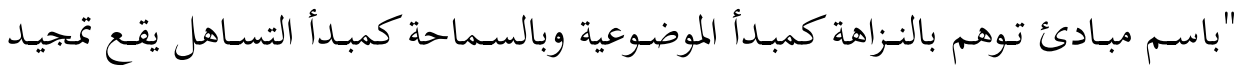

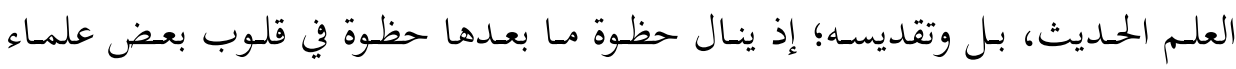

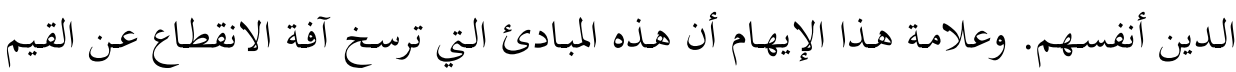

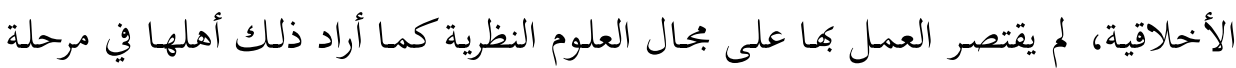

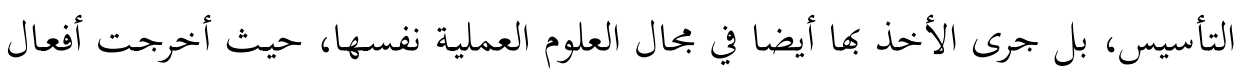

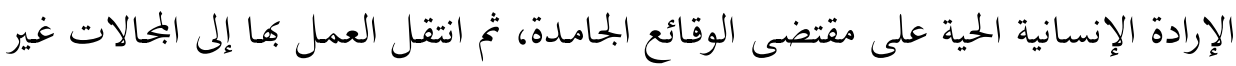

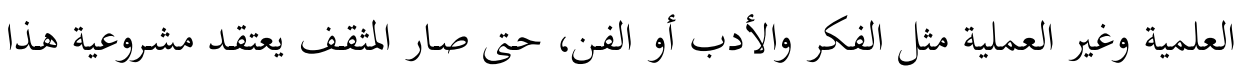

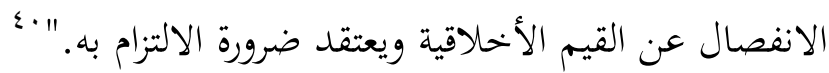

وقد أسهم هذا المبدأ الإبستمولوجي في مزيد من التفسير المادي للتحاليل النفسية، أنداء

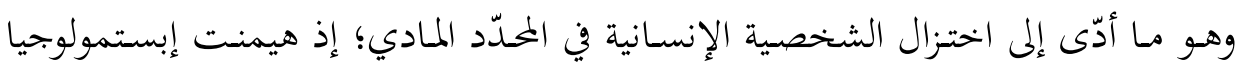

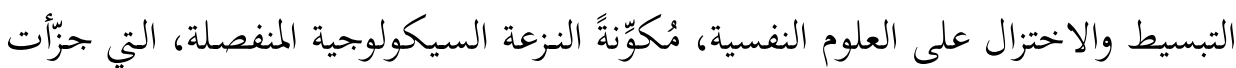

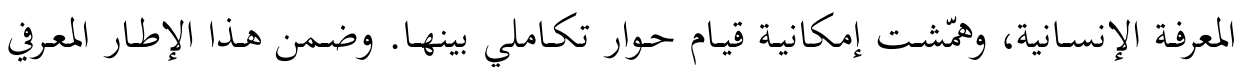
• عبد الرمن، سؤال الأخلاق: مساهمة في النقد الأخلاقي للحداثة الغربية، مرجع سابق، صبه. 
التبسيطي الاختزالي، جرى استبعاد منظومة القيم من العلاجات النفسية؛ نظراً إلى اتصالها

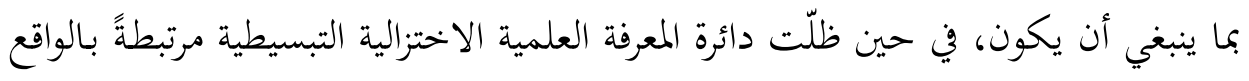
الموضوعي القائم.

بحمل القول إنّ إبستمولوجيا الفصل تخلّقت ضمن الإطار المعريف الذي "سعى العلم

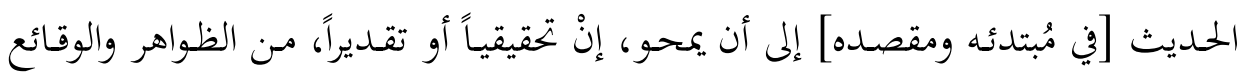

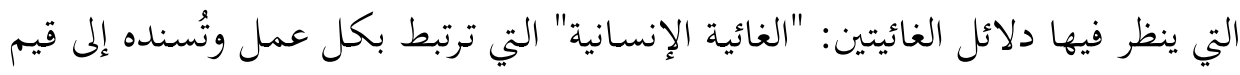

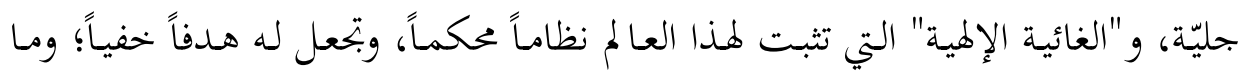

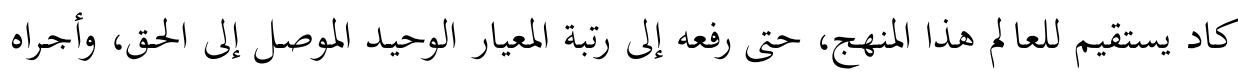

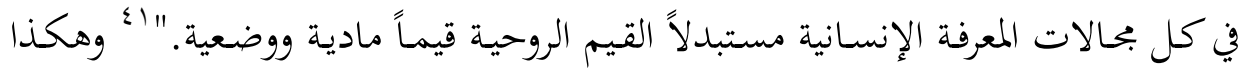

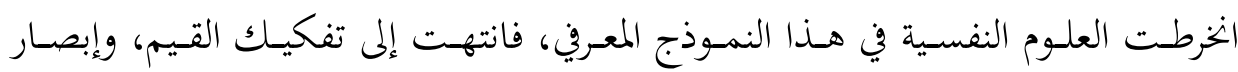

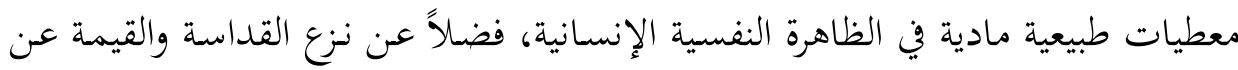

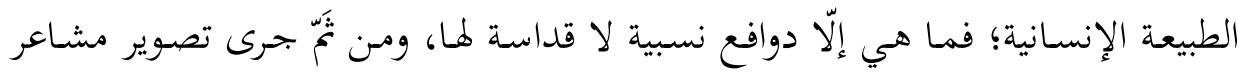

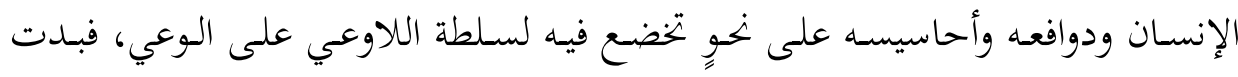

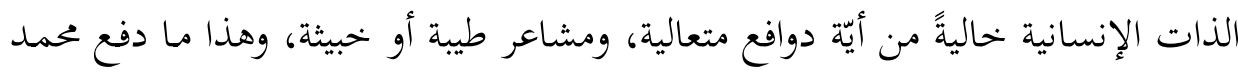

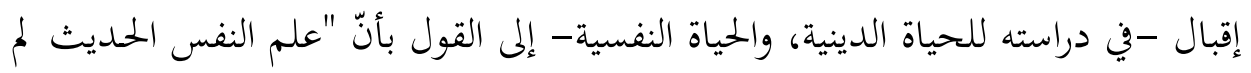

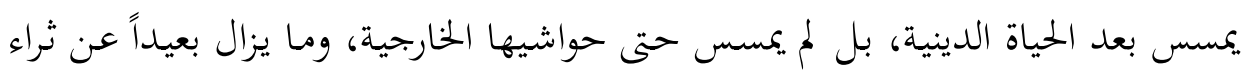

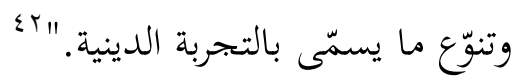

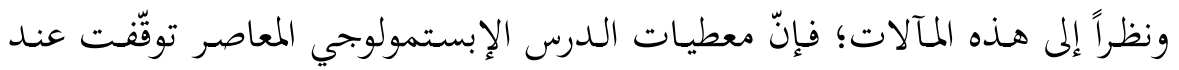

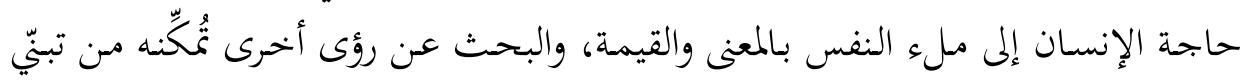

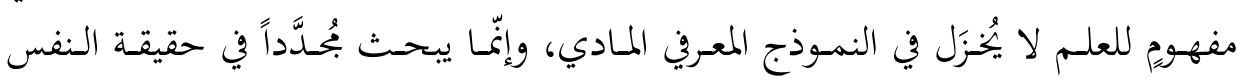

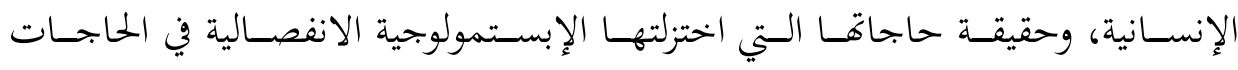

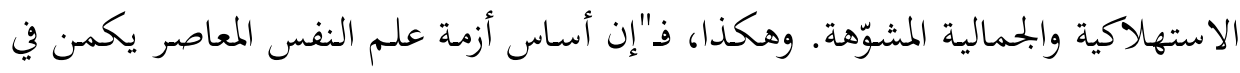

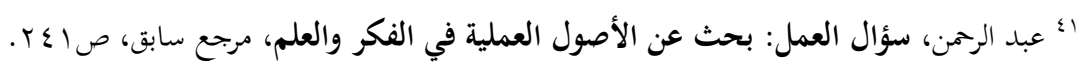

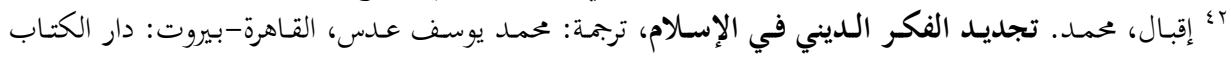




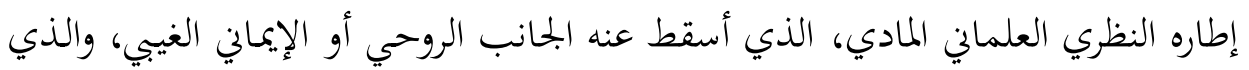

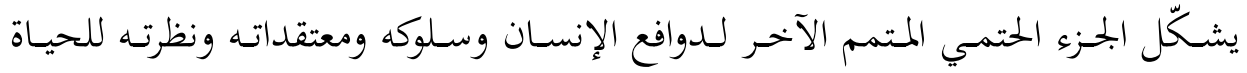

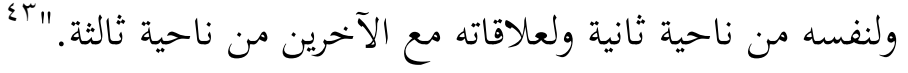

ثالثاً: القيم الأخلاقية وتسديد العلوم النفسية: حاكمية القيم

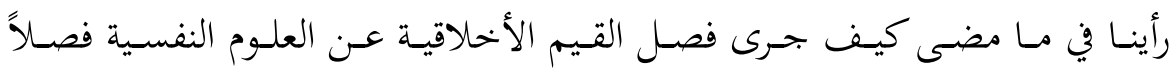

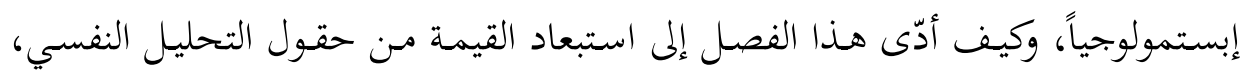

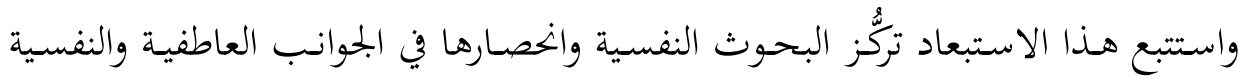

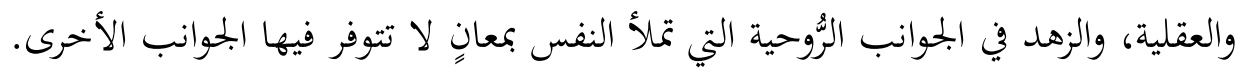
إنّ هذه البنية الفلسفية في تصوير المعرفة لم تعد قادرة على علاج المشكلات النفسية

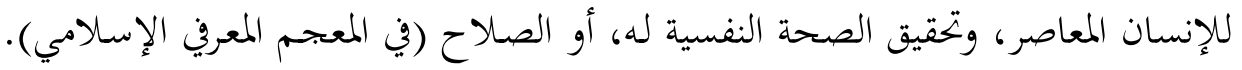

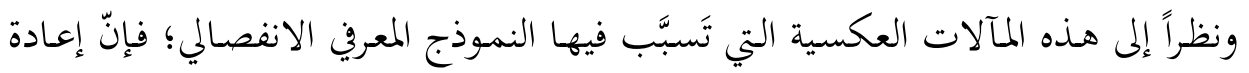

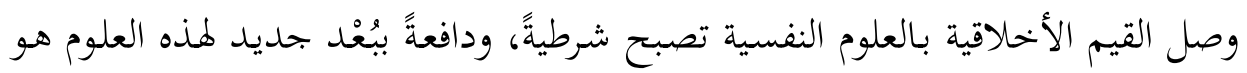

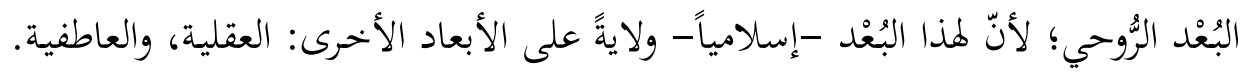

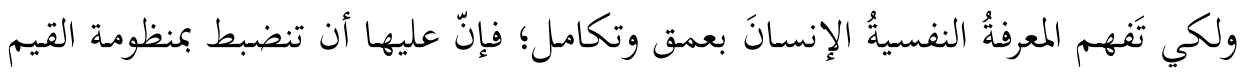

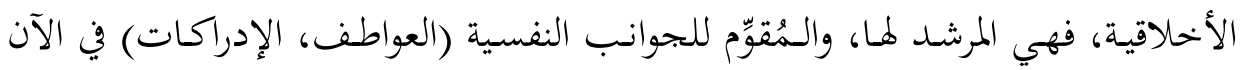

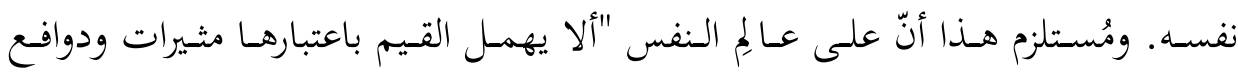

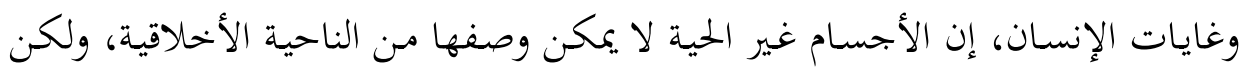

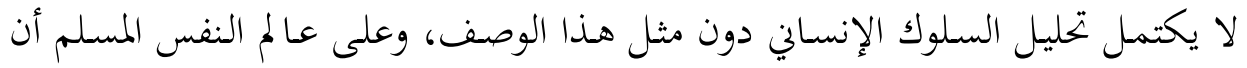

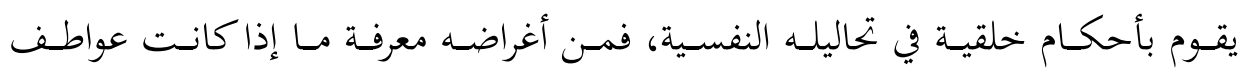

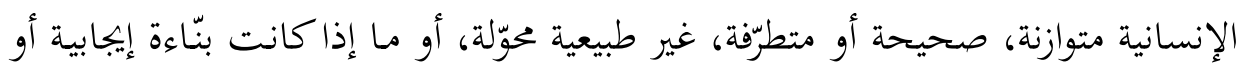

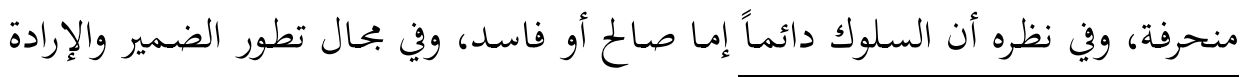

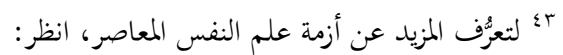
- العاني، نزار سعيد. "أزمة علم النفس المعاصر في النظرية ومصادر المعرفة المنهجية والمعايير"، إسلامية المعرفة، 


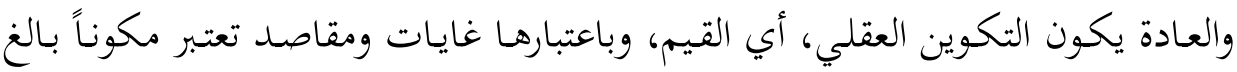

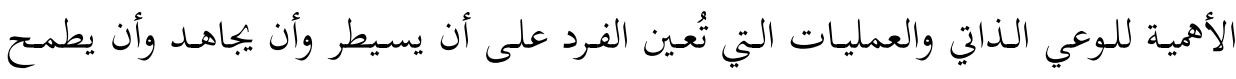

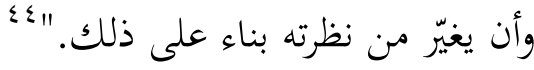

والمتصفّح للتاريخ المعرفي النفسي في الفكر الإسلامي، واجتهادات علماء الإسلام

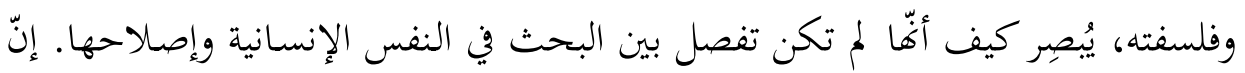

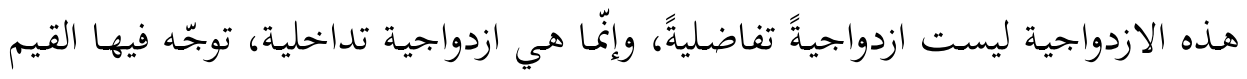

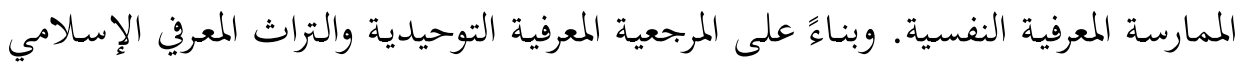

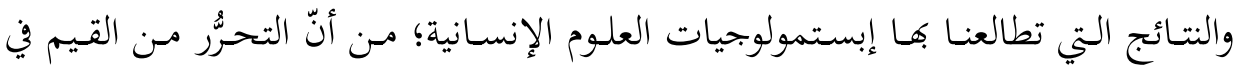

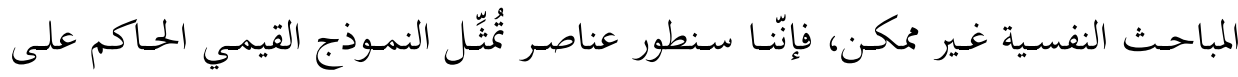

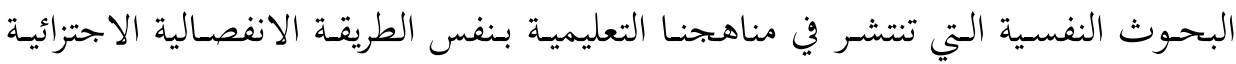

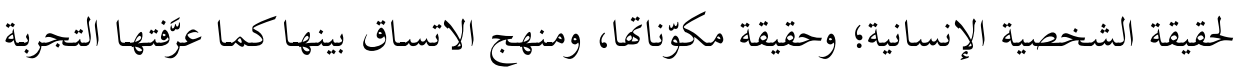

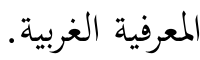

\section{1.النموذج القِيمي الحاكم: نموذج الممارسة التراثية الإسلامية:}

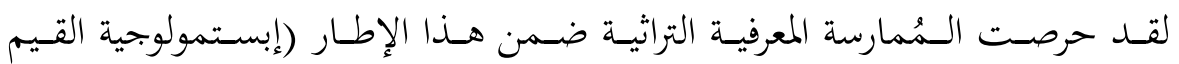

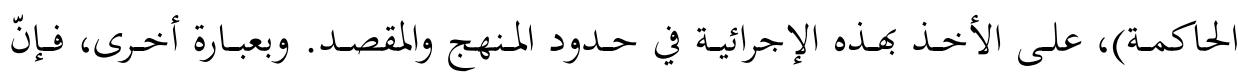

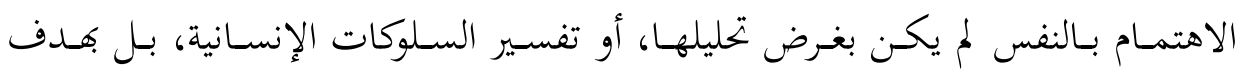

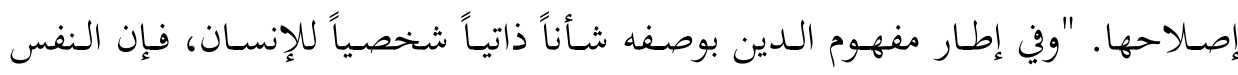

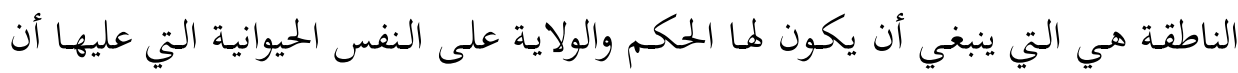

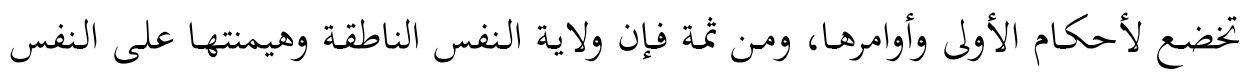

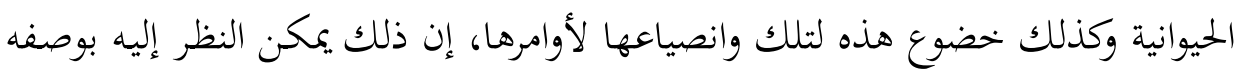

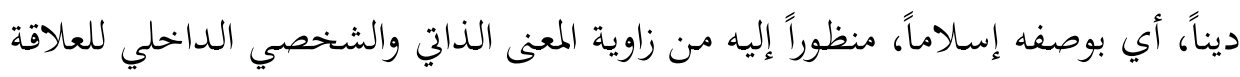

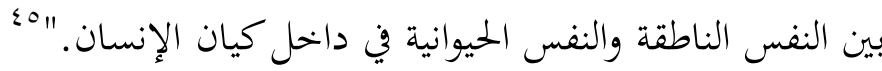

ك؛؛ الهاشي، عبد الحميد. صبغ علم النفس بالصبغة الإسلامية، ضمن: إسماعيل الفاروقي وآخرون، العلوم الطبيعية

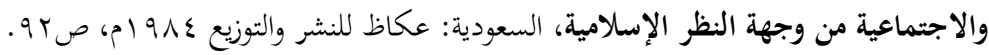

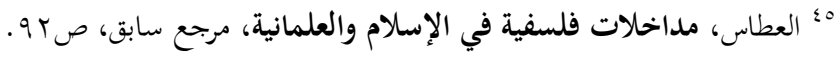


مّمّ تقدّم بند أنّ هدف دراسة النفس الإنسانية هو فهم مركّباها وعناصرها، ومداواتها

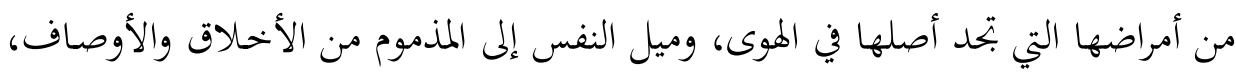

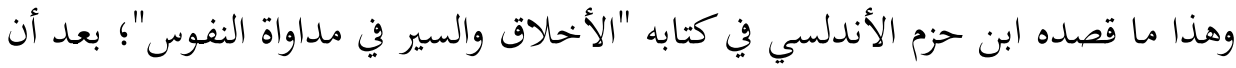

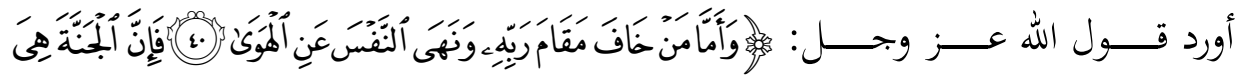

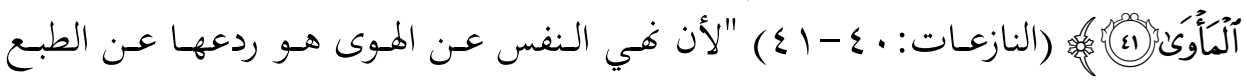
الغضبي وعن الطبع الشهواني؛ لأن كليهما واقع تحت موجب الفي الهوى فلم يبق إلا استعمال

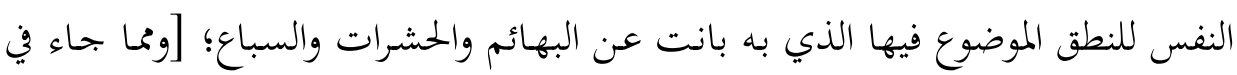

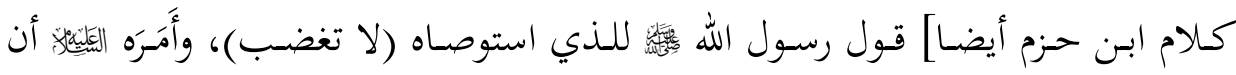

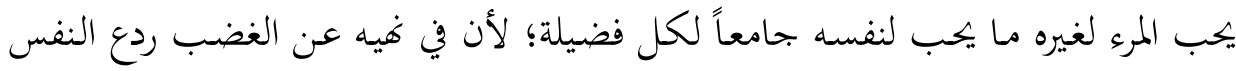

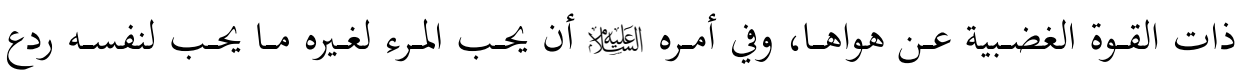

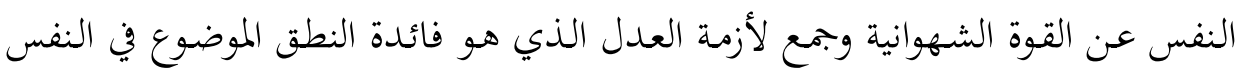

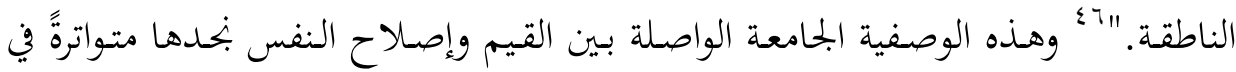

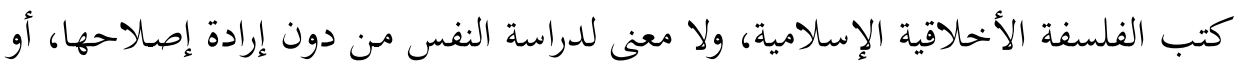

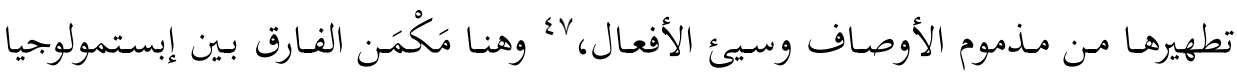

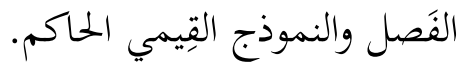

وتُعَدِّ مناهج المتصوفة في بحثهم عن آفات النفس والقلوب والجموارح مسالكَّ قويةً

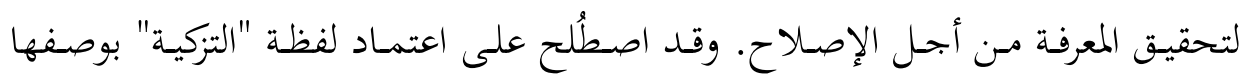

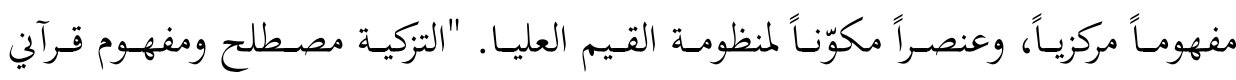

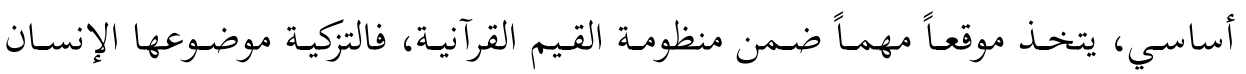
المستخلف، وهو موضوع الإصلاح في الواقع الإنساني. إصلاح الفرد والجماعة والأمة...

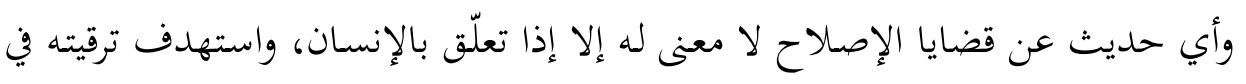
بـ الأندلسي، ابن حزم. الأخلاق والسير في مداواة النفوس، تقديم: عبد الله السبت، الإمارات العربية المتحدة: دار

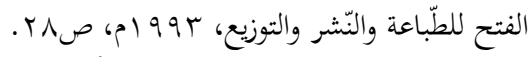
vء انظر: صبحي، أممد محمود. الفلسفة الأخلاقية في الفكر الإسلامي: العقليون والذوقيون أو النظر والعمل،

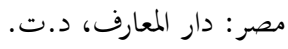


مراتب التزكية. والتزكية هدف العمران ووسيلته، فهي ليست مشاعر وخلجات وخواطر نفسية، مقصورة على مستوى الإصلاح، بل تدخل في صميم البناء الاجتماعي والعمران

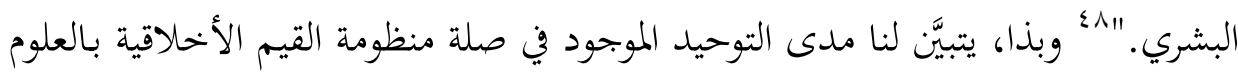
النفسية؛ تأسيساً، وقصداً.

\section{r l. النكامل بين القيم الأخلاقية الحاكمة والعلوم النفسية:}

ليس القصد من رفع القيمة الخلقية إلى رتبة عنصر حاكم هو بتزيء العلوم النفسية،

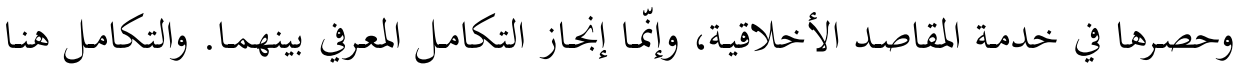

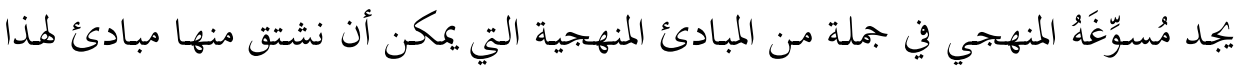

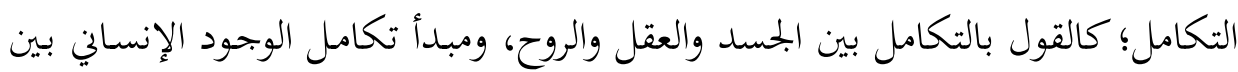

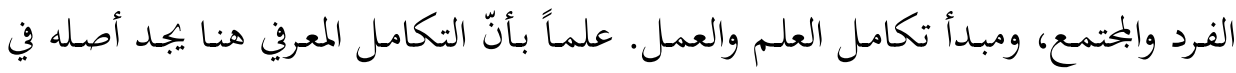

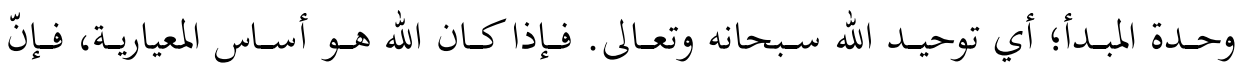

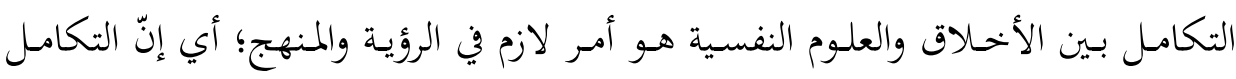

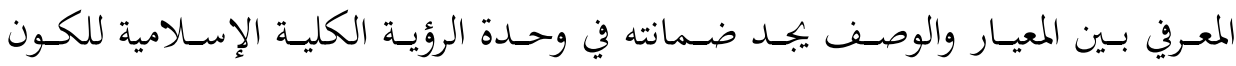

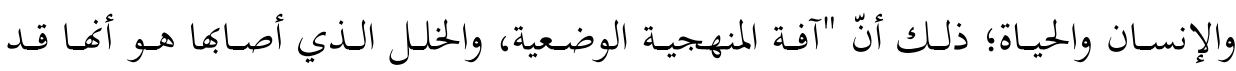

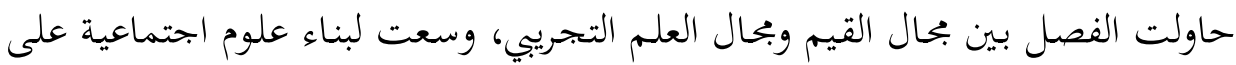

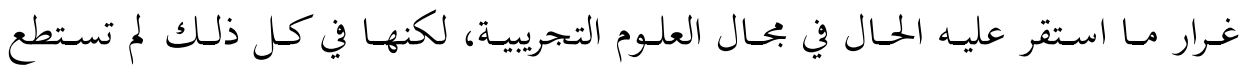

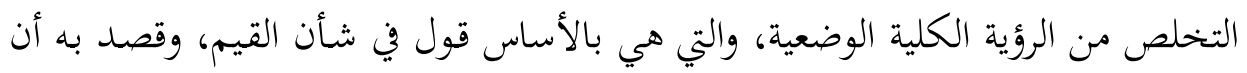

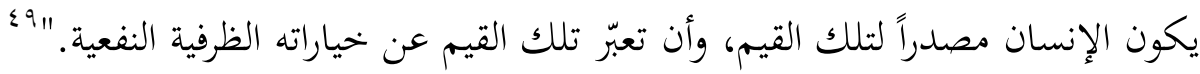

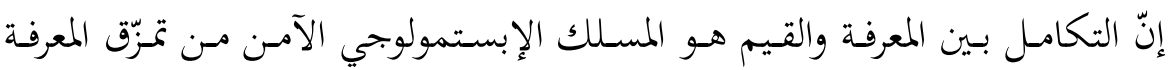

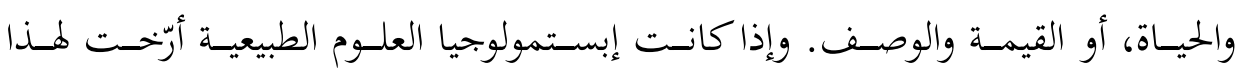
^^ ملكاوي، فتحي حسن. منظومة القيم العليا: التوحيد، التزكية، العمران، واشنطن: المعهد العالمي للفكر

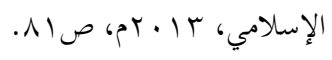

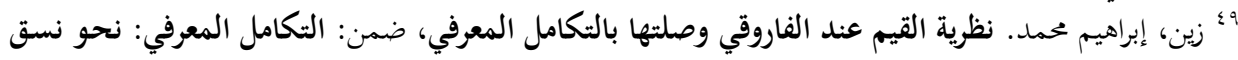

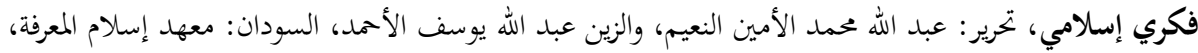




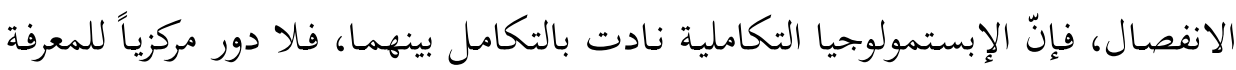

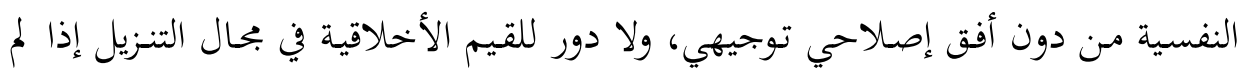

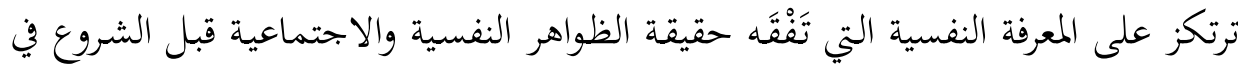

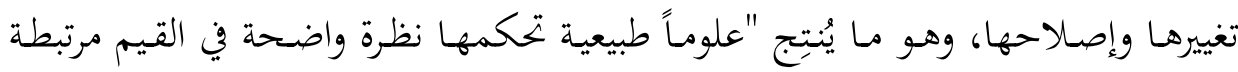

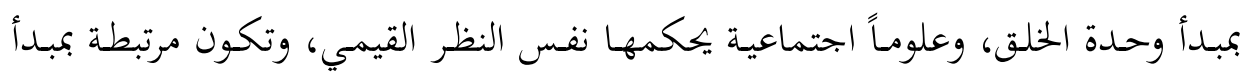

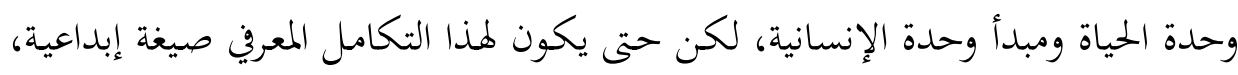

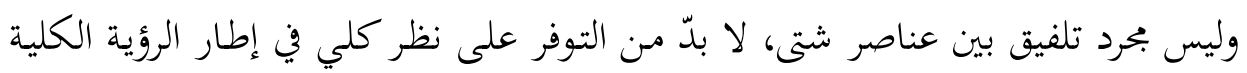

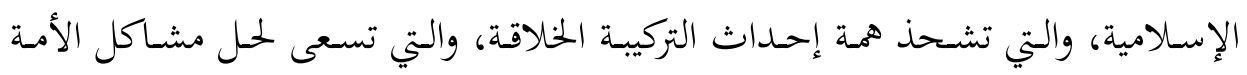

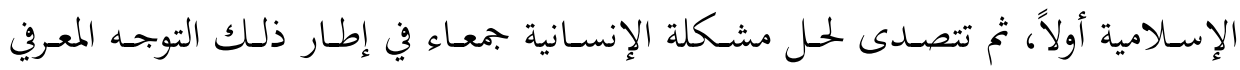

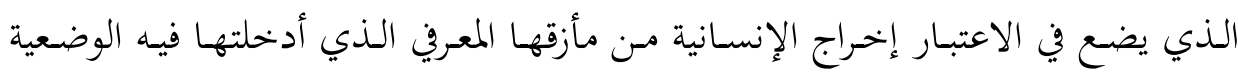

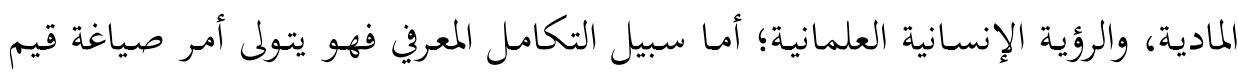

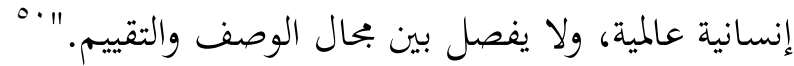

وبهذا الإجراء المعرفي والمنهجي يتم الوصل التكاملي بين القيمة والعلوم النفسية ضمن

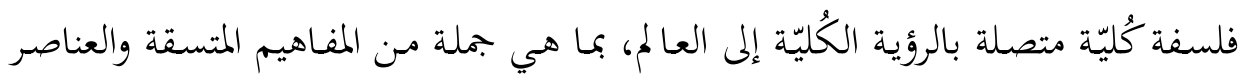

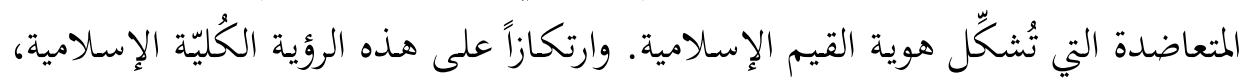

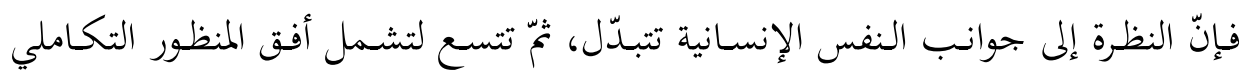

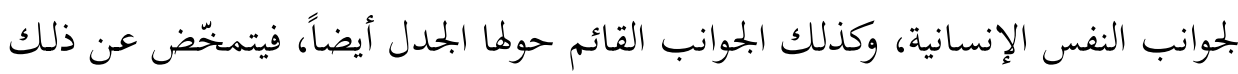

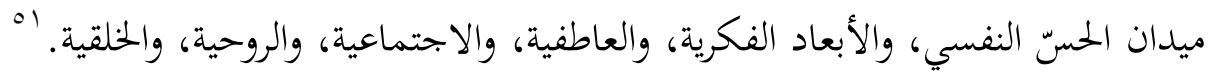

\section{رابعاً: إبستمولوجية القيم الأخلاقية الحاكمة ومقاصدها}

إنّ هذه التكاملية بين القيم الأخلاقية والعلوم النفسية ليست جهداً تنظيرياً خالصاً،

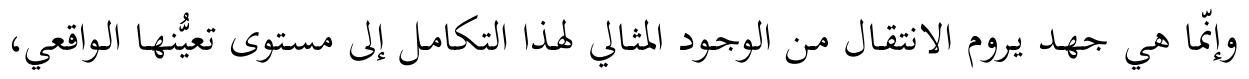


ولا يعني عدم التعيُّن هذا استحالة الفعل الأخلاقي، بل قداسة الإطار الحاكم، وتعاليه،

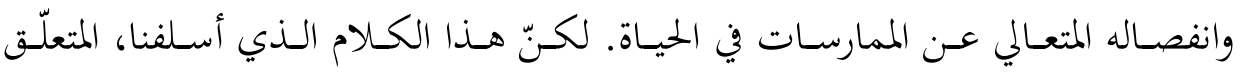
بحاكمية القيم الأخلاقية وتكاملها مع العلوم النفسية، يُقصَد أيضاً في هذا المشروع؛ سعياً

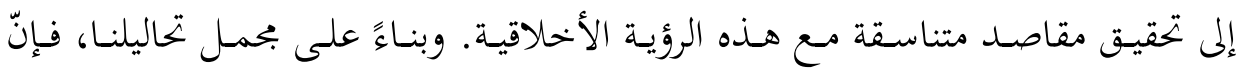
المقاصد الكبرى التي يجوز لنا رصفها ثمرات من هذا التنظير المنهجي هي:

\section{ا مقصد الصلالح:}

إنّ الصـلاح في حقيقته حالة مـن التـوازن الرُوحي والنفسي للإنسـان، تتحقِّق فيها

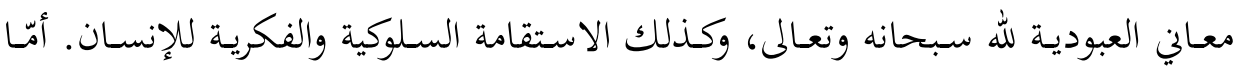

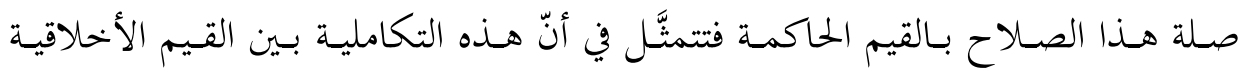

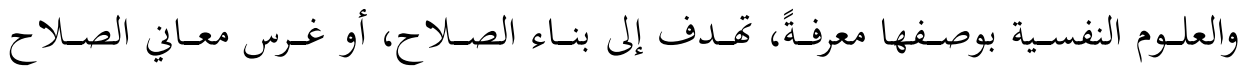
والاستقامة في الإنسان؛ لأنّ "طلب المعرفة في الإسلام غايته بناء الإنسان الصالح .... لأن

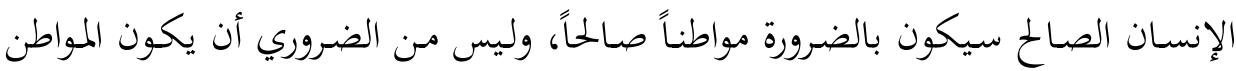

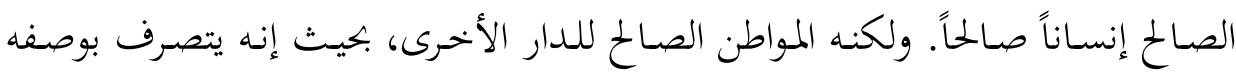

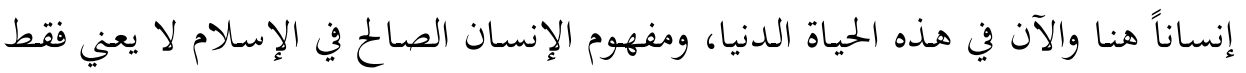

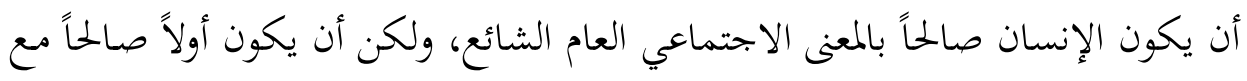

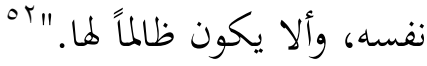

والصالاح في العلم والعمل تسبقه معرفة النفس؛ لأنّه بمعرفتها يتم التمييز بين قوى النفس وحاجاتها. أمّا بالمحاهدة فيُرسَم طريق السعادة الحقيقية. يقول أبو حامد الغزالي في

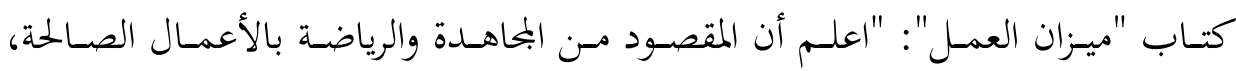

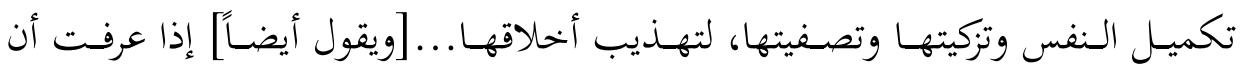

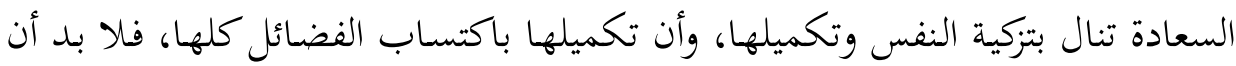
تُعرف الفضائل جملة وتفصيلاً. "rاله

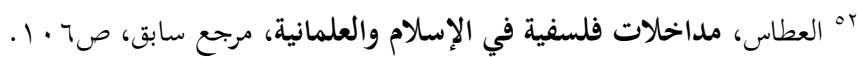

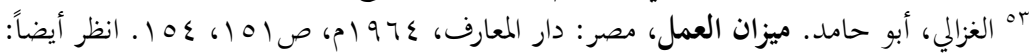




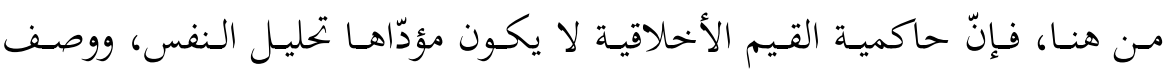

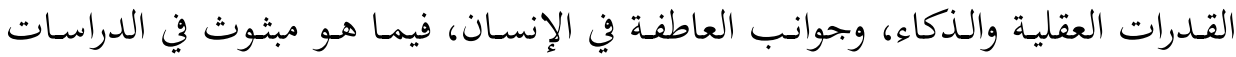

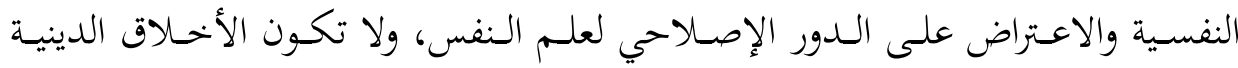

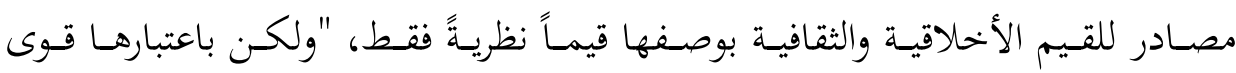

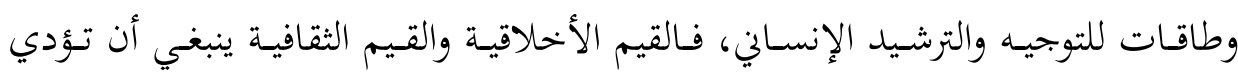

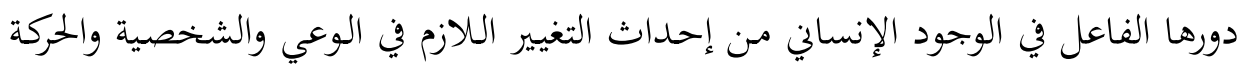

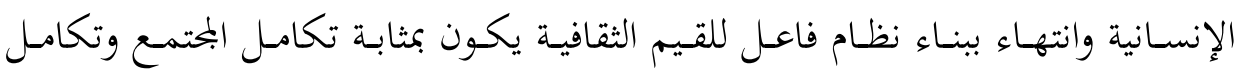

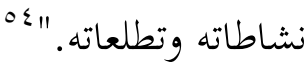

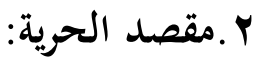

إنّ معرفة النّفس معرفة علمية، ثُّ العمل على إصلاحها بأن تكون مستقيمةً معتدلةً

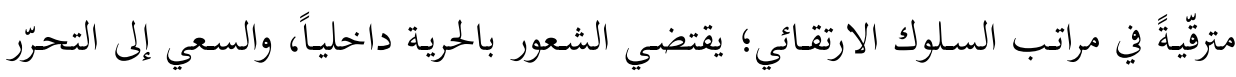

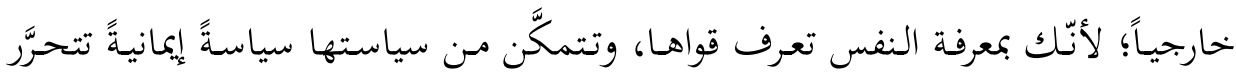

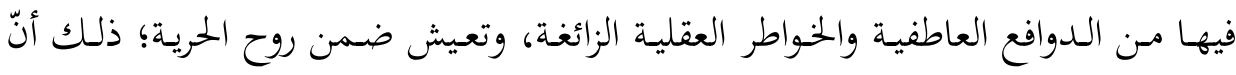

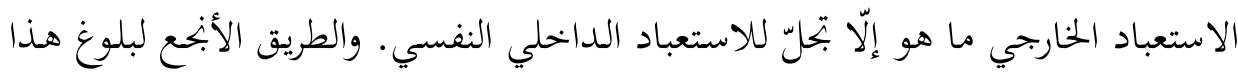

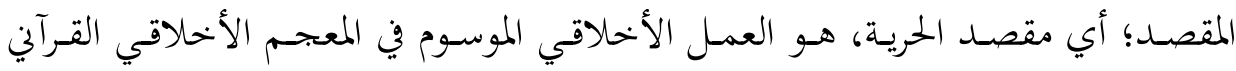

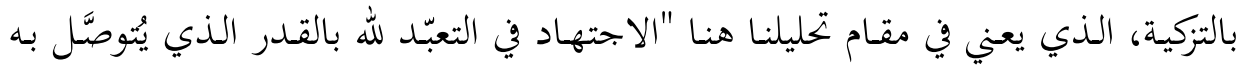

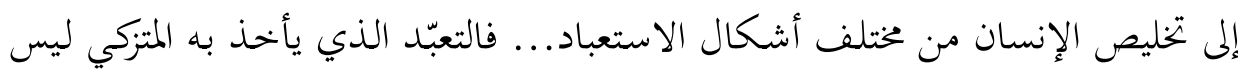

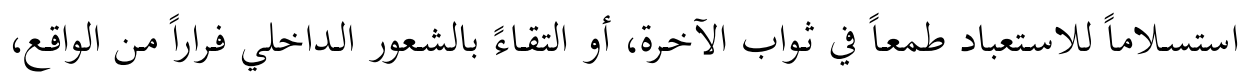

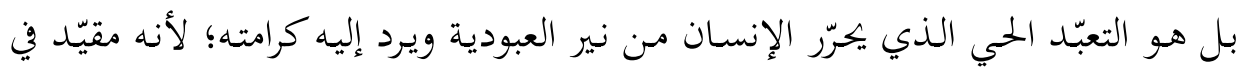

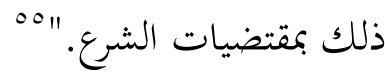

- الكيلاني، ماجد عرسان. مقومات الشخصية المسلمة أو الإنسان الصالح، قطر : وزارة الأوقاف والشؤون

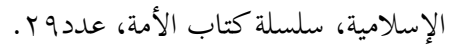

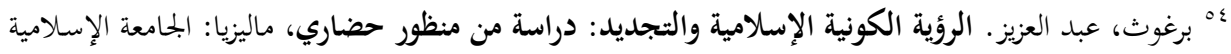

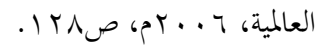
٪. عبد الرمن، طه. سؤال العمل: بحث عن الأصول العملية في الفكر والعلم، مرجع سابق، ص. 17. 
ويرى ابن عاشور -بعد استقرائه نصوص الشريعة- أنّ الحريـة مقصـد مـن مقاصد

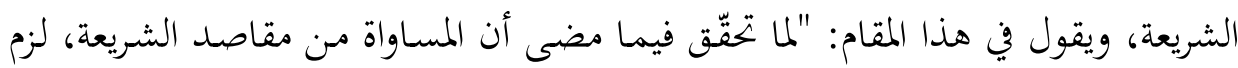

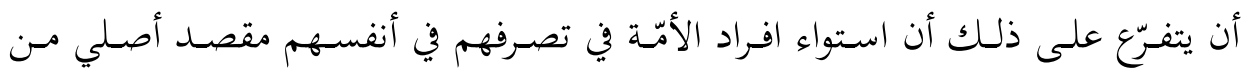

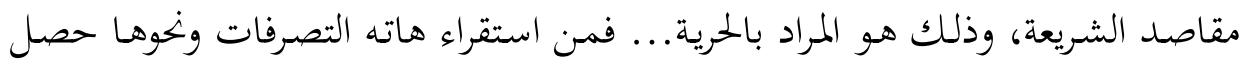

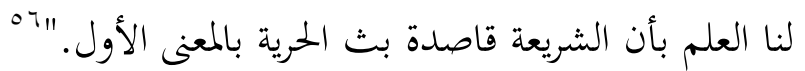

والحرية بوصفها قيمةً نفسيةً واجتماعيةً وحضاريةً يمكن أن تكون معياراً قيمياً على

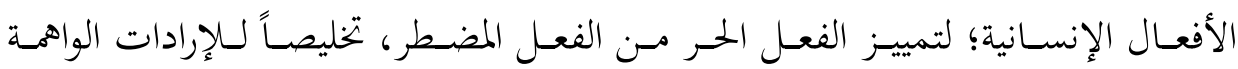

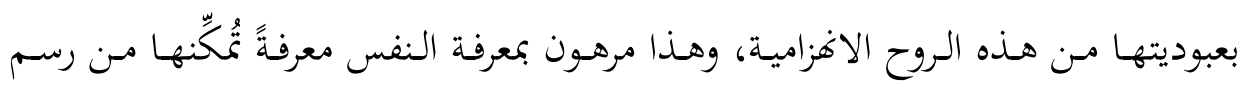
الطرائق الحيويـة التي تتجـاوز مشـاعر الضـفف والـوهن، وتــوّي مشـاعر الحريـة والتحـرّر والحركة. وبحسبب مقالة العبودية الطوعية لـ(إيتيان دولابويسي)، فبإنّ فقدان الحرية مردّه العبودية الطوعية الموجودة في نفوس الذين قبلوا الاستعباد بـلاً من هذه الحرية؛ أي إنّا مسألة نفسية في مبتدئها ومنتهاها، فالحاكم المستبدّ لا يكتسب قوته من ذاته المستعلية،

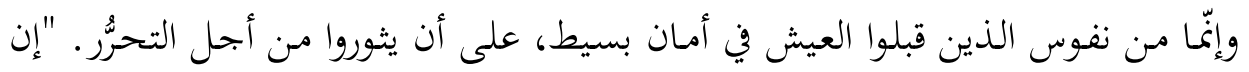

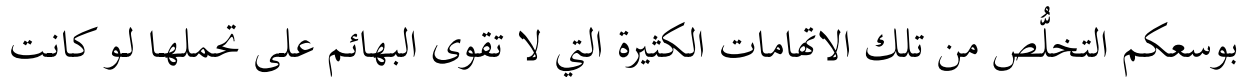

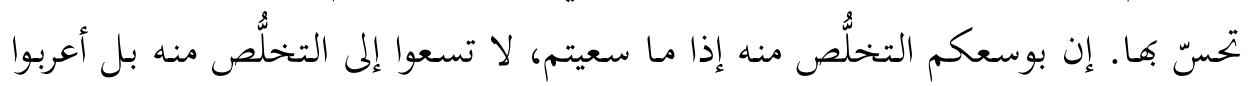
عن الرغبة في ذلك فقط، احزموا أمركم على التخلص فهائياً من الحنوع وها أنتم أحرار.

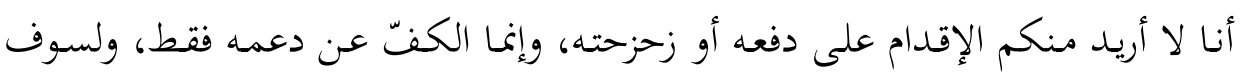

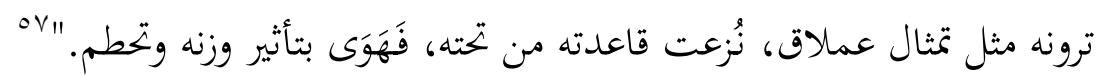
moral إنّ الحرية الراشحة من نماذجية القيم الأخلاقية الحاكمة تثمر أيضاً الفاعلية

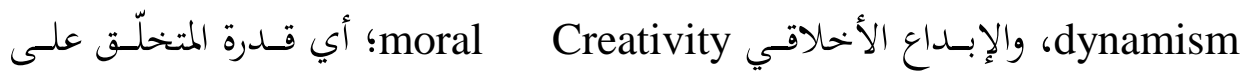
التفاعل، والفعل، والحركة، وتفعيل قيم جديدة برؤية العالم والحياة رؤيةً إيجابيةً، لا رؤيةً

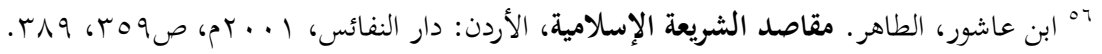

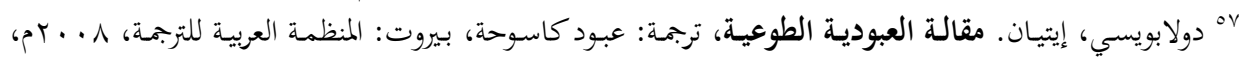




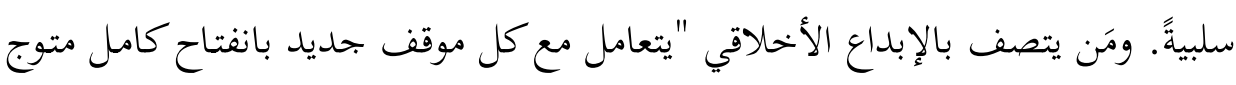

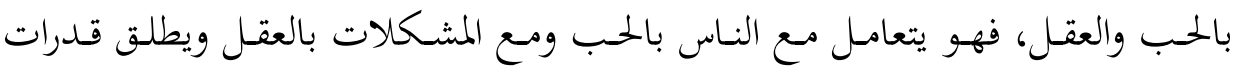

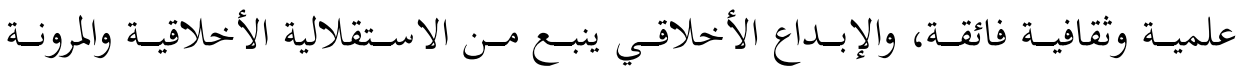

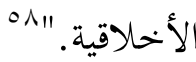

من هنا، تكون الحرية مقصداً جليلاً من مقاصد إبستمولوجية القيم الحاكمة، ويجدر

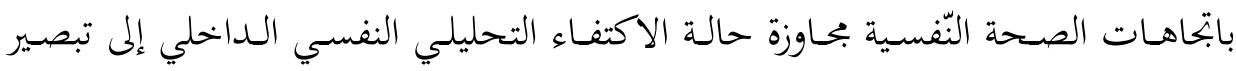

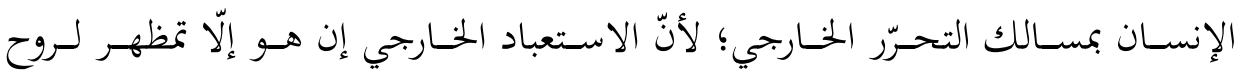
المستعبد داخلياً.

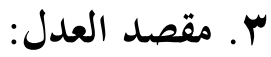

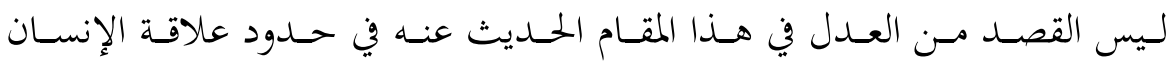

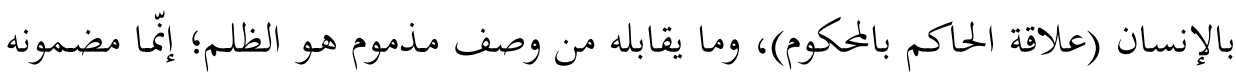

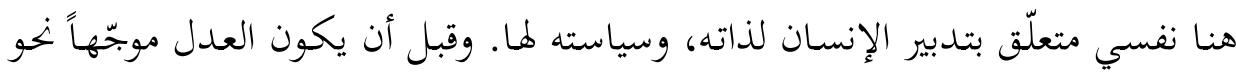

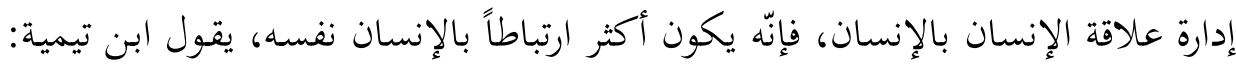

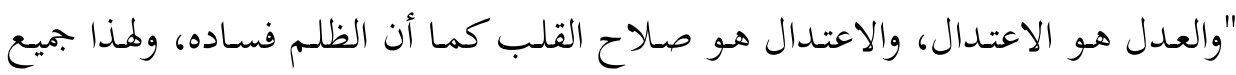

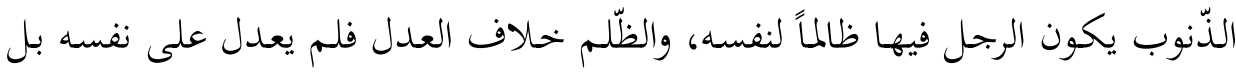

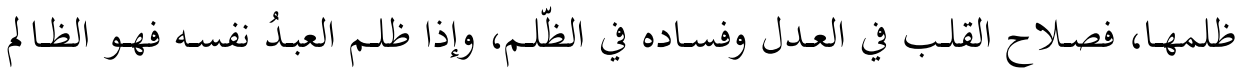

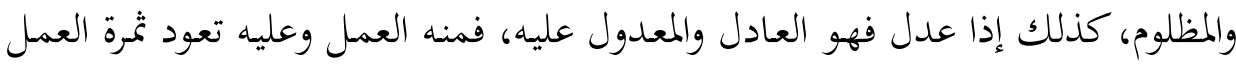

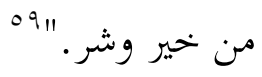

وقد أشرنا سابقاً إلى أنّ الاستبداد الدّاخلي هو المدخل إلى الاستبداد الخارجي، وأنّ

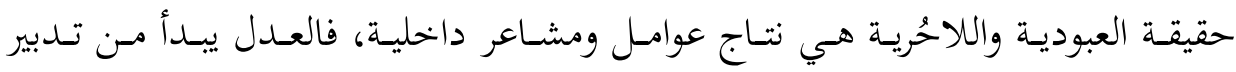

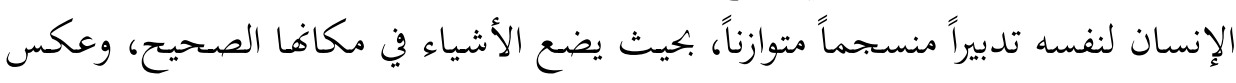

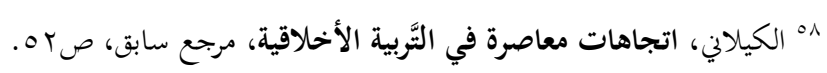

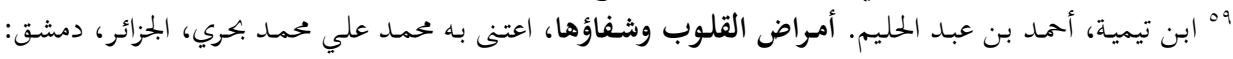

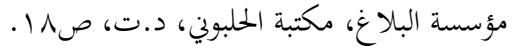




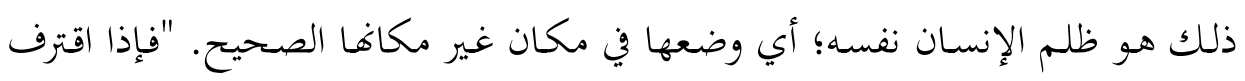

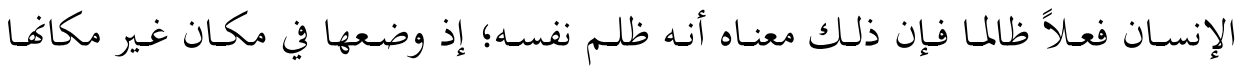

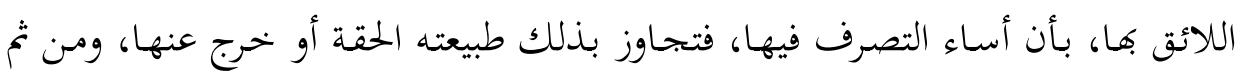

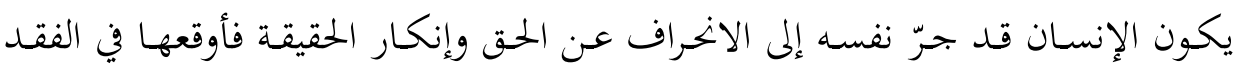

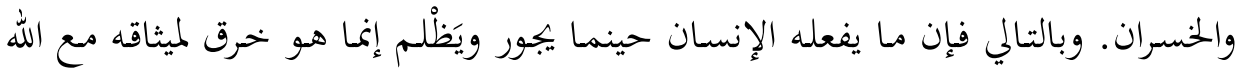

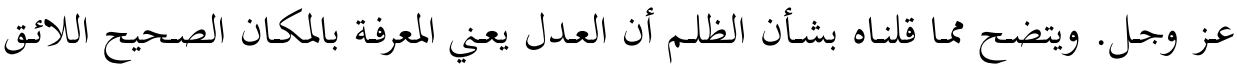

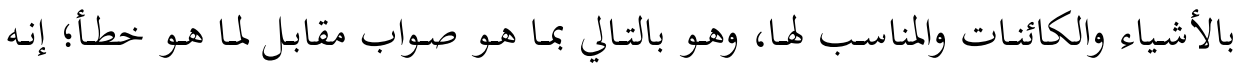

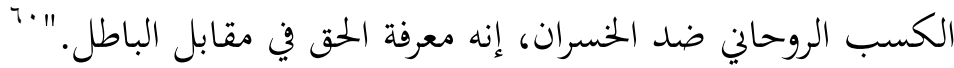

إذن، العـل هـو نظام في المنهج، وترتيـب للأشياء في مكاهـا الصحيح، والإخهلال

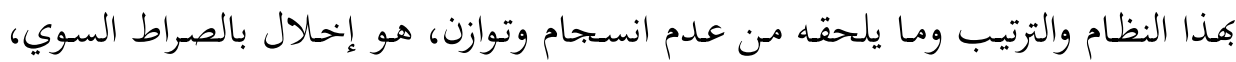

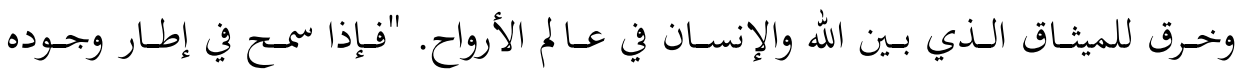

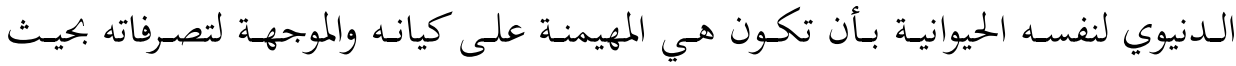

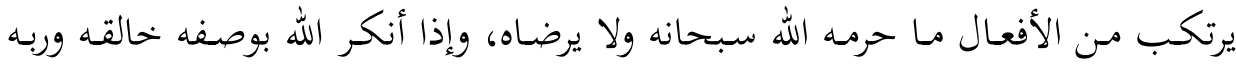

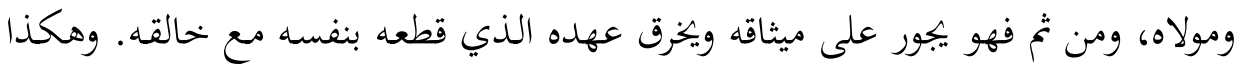

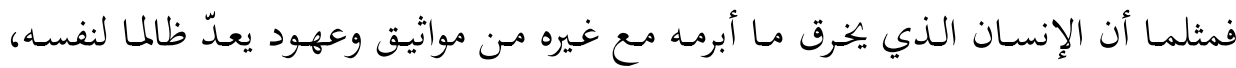

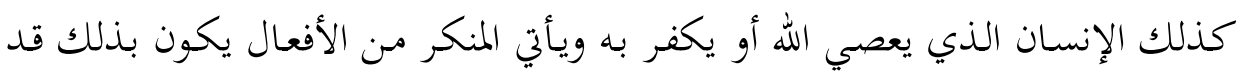

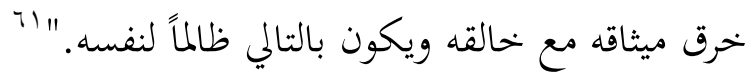

وتأسيساً على ذلك، يمكن فهم الأخلاق بصورة معرفية متكاملة مع العلوم النفسية،

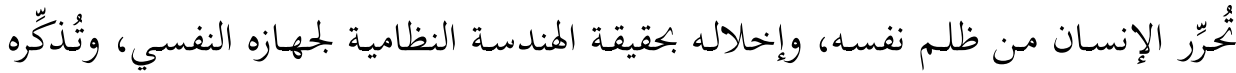
بالميثاق الأخلاقي الأصلي الذي تعهّد فيه لله بأداء نسك العبادة، وتحقيق حاكمية روحه الأخلاقية في مختلف جوانب الحياة الأخرى.

والعدل بالمفهوم الآنف الذكر هو مقدّمة إلى إقامة العدل بين الإنسان والإنسان في

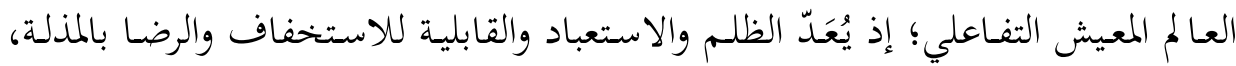


مظاهرَ للظلم، وإخلالاً بتدبير الإنسان لصلته بعناصر الواقع والخارج، وفق نظام شرّعه الله

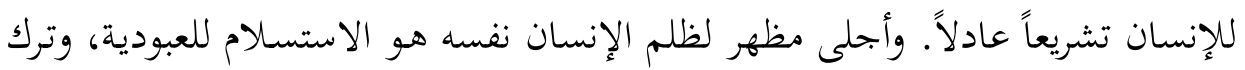

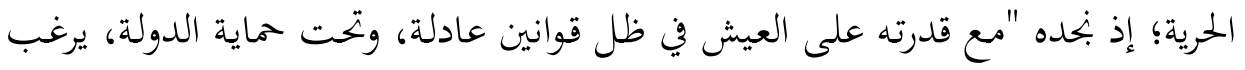

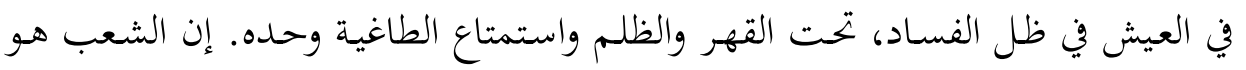

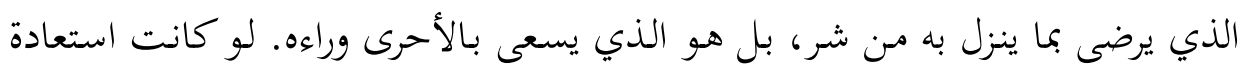

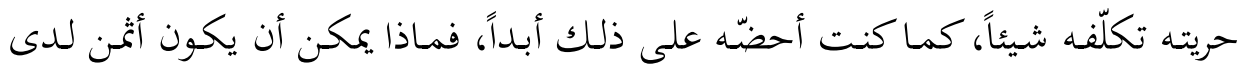

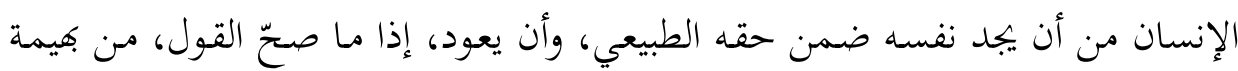

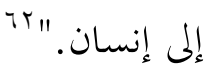

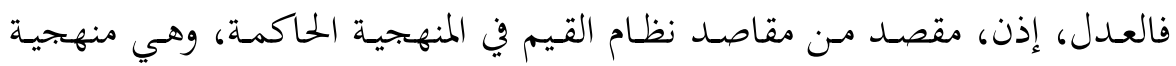

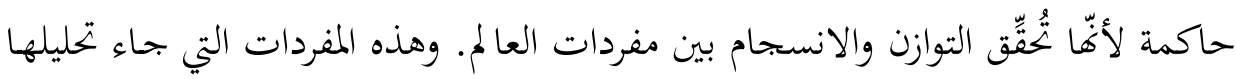

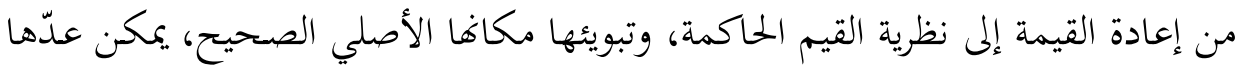

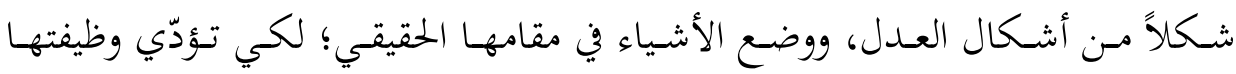
ودورها المنوط بها بما يتفق والنظرة إلى العالم.

خاتمة:

بعد هذا التّطواف في جوانب إعادة الاعتبار لنظرية القيم الحاكمة، في صلتها بالعلوم

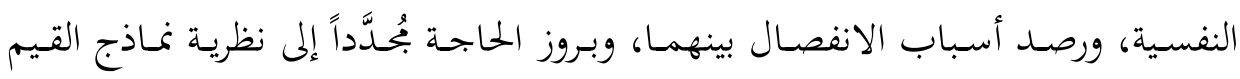
الحاكمة؛ فإنبّا نخلص إلى الاستنتاجات الآتية: - عدم اقتصار مفهوم القيمة على حقل معرفي خخصوص (دائرة القيم الأخلاقية،

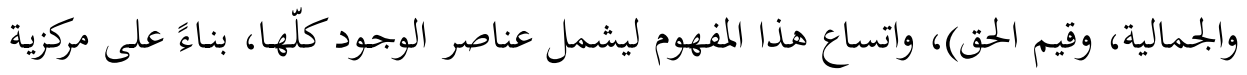

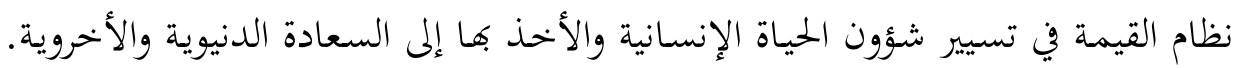

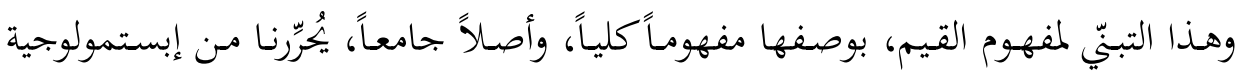


الفصل التي هيمنت على التنظيرات المعرفية والقيمية، ويصلنا بالرؤية الإسلامية التي تبصر

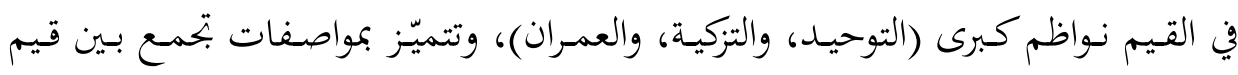

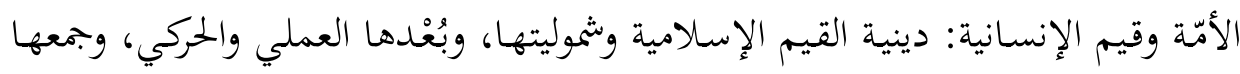
بين الفردي والجماعي، وتباهما وحركتها. - تَعرُّرُ إبستمولوجية الفصل للنَّقد، وتحميلها مسؤولية إشـاعة قيم العَدَمية وإفقاد المعنى لدلالته، بعد قمميشها للقيمة في علاقتها بمنظومة العلوم النفسية. يفتح في المقابل

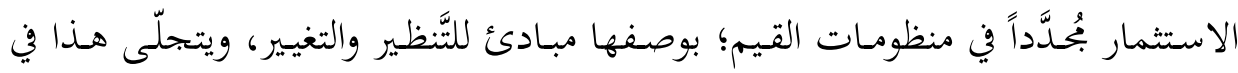

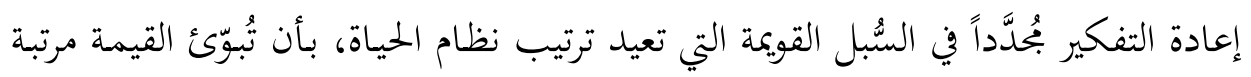

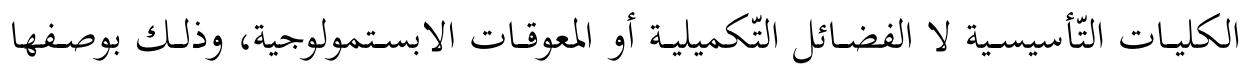

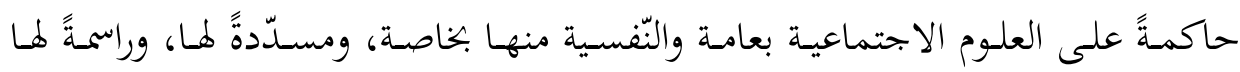
المقصد والوجهة المستقيمة، المعتدلة والمتوازنة. - إعادة الصلة الممزّقة بين الأخحاق والعلوم النفسية بوصفها أقوى المسالك المنهجية

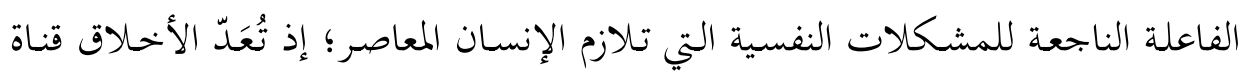

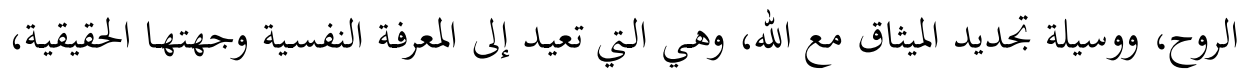

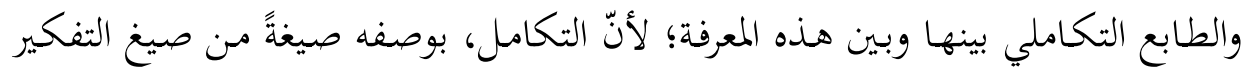

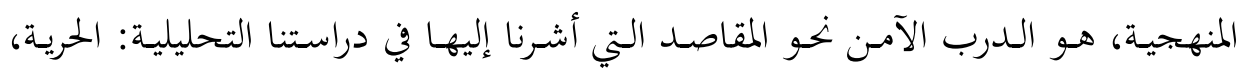
والتكامل المعرفي، والعدل.

- نقل منهجية القيم من التنظير إلى حيّز الممارسة؛ فبإنّ التربية والتعليم هما الوعاء ألماء

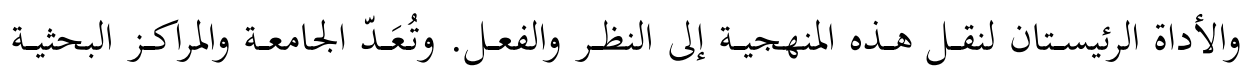

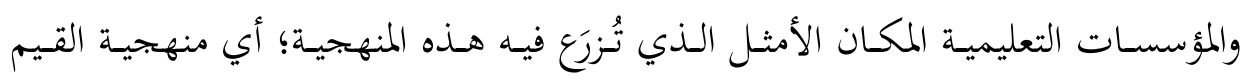
بوصفها نموذجاً معرفياً حاكماً، وذلك بتجديد مناهج التعليم ومضامينه التي يتكوَّن وَفْقَها

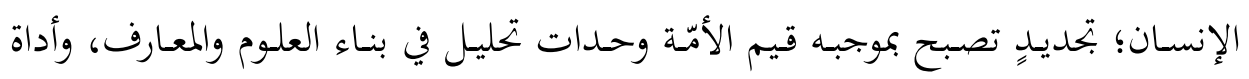

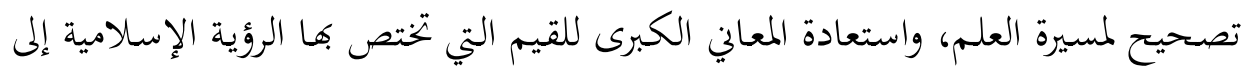

